\section{Ankara Üniversitesi Eğitim Bilimleri Fakültesi Özel Eğitim Dergisi}

2021, 22(3), 543-567
ARAŞTIRMA

Gönderim Tarihi: 03.01.20

Kabul Tarihi: 29.10.20

Erken Görünüm: 21.01.21

\title{
Görme Yetersizliğinden Etkilenmiş Çocuklar ile Gören Çocukların Duygu İfadelerine Verdikleri Tepkilerinin Karşılaştırılması
}

\author{
Hale Çotuk $($ iD 1
}

\author{
Selda Özdemir ${ }^{(D)} 2$
}

Öz

Giriş: Yüz ifadeleri insanlar arasında duygu alışverişini sağlamaktadır. Bu araştırmada görme yetersizliği olan ve gören çocukların oyun sırasında akranın sergilediği mutlu ve üzgün duygu ifadelerine verdikleri tepkiler karşılaştırılarak incelenmiştir.

Yöntem: Araştırmanın katılımcılarını 4-6 yaş aralığında 20 görme yetersizliği olan çocuk (10 az gören, 10 ağır görme yetersizliğinden etkilenen) ve 20 gören çocuk oluşturmuştur. Araştırma kapsamında, mutlu ve üzgün duygu durum bağlamları oluşturularak akranların mutlu ve üzgün duygu ifadelerini yansıtmaları sağlanmıştır. Akranının sergilediği duygu ifadelerine yönelik görme yetersizliği olan ve gören çocukların verdikleri duygu tepkileri gözlemlenmiştir. Araştırmada, katılımcı çocukların mutlu ve üzgün duygu ifadeleri tepkileri Görmezden Gelme, Fiziksel Yakınlık, Uyumlu Tepki, Dikkati Dağıtma, Tepki Vermeden Dikkatini Yöneltme, Uyumsuz Tepki ve Fiziksel Heyecan Tepkisi kategorilerinde kodlanmıştır.

Bulgular: Araştırmanın bulguları, görme yetersizliği olan çocuklar ile gören çocukların duygu ifadelerine verdikleri tepkiler arasında farklılıklar olduğunu göstermiştir. Bulgular görme yetersizliği olan çocukların duygu durumlarında gören akranlarına oranla daha fazla görmezden gelme davranışları sergilediklerini göstermiş̧ir.

Tartışma: Araştırmada çocukların mutlu ve üzgün duygu ifadelerine verdikleri tepkiler incelenmiştir. Araştırmanın sonuçları tartışılmış, ileri araştırmalara yönelik önerilere yer verilmiştir.

Anahtar sözcükler: Görme yetersizliği olan çocuklar, az gören çocuklar, duygular, duygu ifadeleri tepkileri, mutlu, üzgün.

Atıf için: Çotuk, H., \& Özdemir, S. (2021). Görme yetersizliğinden etkilenmiş çocuklar ile gören çocukların duygu ifadelerine verdikleri tepkilerinin karşılaştırılması. Ankara Üniversitesi Eğitim Bilimleri Fakültesi Özel Eğitim Dergisi, 22(3), 543-567. https://doi.org/10.21565/ozelegitimdergisi.669915

\footnotetext{
${ }^{1}$ Sorumlu Yazar: Arş. Gör., Gazi Üniversitesi Eğitim Fakültesi, E-posta: halecotuk@gmail.com, https://orcid.org/0000-00034639-9216

2Prof. Dr., Hacettepe Üniversitesi Eğitim Fakültesi, E-posta: seldaozdemir@hacettepe.edu.tr, https://orcid.org/0000-0001$\underline{9205-5946}$
} 


\section{Giriş}

Yaşam boyu gelişen duygusal yetkinlik; duygu ifadelerini ve deneyimleri, bireyin kendi duyguları ile diğer insanların duygularını anlamasını ve duygu düzenleme becerilerine sahip olmasını içermektedir (Denham vd., 2007). Araştırmacılar, bebeklerde doğumdan itibaren hangi duyguların mevcut olduğu konusunda ikiye ayrılırken, duygu durumlarının çocuklarda gelişimi konusunda hemfikirdirler. Araştırmacıların bir kısmı duyguların bebeklik döneminden itibaren ilk olarak memnuniyet ile sıkıntılı olmak arasında iki temel duruma bağ lı olarak gözlendiğini belirtmekte (Lewis, 2008), diğerleri ise bebeklerin mutlu, meraklı, şaşkın, korkmuş, kızgın, üzgün ve iğrenmiş gibi temel duygular ile doğduklarını ifade etmektedir (Johnson vd., 1982). Söz konusu görüş farklılıklarına rağmen araştırmacılar, duygu durumlarının çocukluk dönemi boyunca duygularla ve duygusal ifade stilleriyle ilişkili olarak geliştiği konusunda hemfikirdirler (Cole \& Cole, 2001).

Alanyazında mutlu, meraklı, şaşkın, korkmuş, kızgın, üzgün ve iğrenmiş gibi duygu ifadeleri doğrudan anlaşılan duygular, dolayısıyla da temel duygular olarak tanımlanmaktadır (Berk, 2002). Duygular, araştırmacılar tarafından farklı şekillerde sınıflandırılmakta ancak tüm sınıflandırmaların ortak özelliği olarak duygular olumlu veya olumsuz duygular olarak ikiye ayrılmaktadır (Santrock, 2004). Temel duygulardan biri olan üzgün duygu durumu, olumsuz ve rahatsız edici bir duygu durumu olmakla birlikte genel olarak iki farklı nedenden dolayı ortaya çıkabilmektedir; ayrılık ve başarısızlık (Reeve, 2005). Temel duygulardan bir diğeri olan mutluluk ise birçok bireyin yaşamak istediği, kişilerin kendini iyi hissetmesini sağlayan olumlu bir duygu olarak kabul edilmektedir (Ekman \& Friesen, 2003). Mutluluk duygusu, keyifli gülüşlerle ve sonrasında coşkulu kahkahalarla gelişimin birçok boyutuna önemli katkılar sağlamaktadır (Berk, 2002). Araştırmacılar tarafından mutlu ve üzgün olmak zıt duygular olarak ifade edilmekte ve bu doğrultuda insanların ayrılık ve başarısızlık sonucunda kendilerini üzgün hissederek halsiz, içe kapanık ve karamsar oldukları; öte yandan kişisel başarılar ve kişilerarası ilişkilerin sonucunda mutlu hissederek coşkulu, dışa dönük ve iyimser olduklarını açıklamaktadırlar (Reeve, 2005).

Duygusal ifadeler, çocuklar için temel iletişim şekli olarak ifade edilmektedir (Wittmer \& Petersen, 2006). Yeni doğan bebekler, ihtiyaç ve isteklerini belirtmek amacıyla ağlama veya sosyal olduklarını hissettikleri durumlarda gülümseme tepkileri göstererek duygu gelişimlerine dair erken ipuçları sergilemektedirler (Papalia vd., 2006). Bebekler gelişimin ilk aylarında göz teması kurmayı, gülümsemeyi ve dokunmayı öğrenmektedirler (Smith, 2001). Bu açıdan bazı araştırmacılar, bebeklerin erken dönemden itibaren insanların yüz ifadelerini ayırt edebildiklerini ve taklit edebildiklerini göstermișlerdir (Field vd., 1982; Meltzoff \& Moore, 1977, 1983). Field ve diğerleri (1982) bir çalışmada yeni doğan bebeklerin (yaklaşık 36 saat) bir yetişkin tarafından sunulan farklı yüz ifadelerini (mutlu, üzgün ve şaşkın) ayırt edebildiklerini ve yetişkinin sergilediği ifadelere yönelik kaş, gözler ve ağız bölgelerindeki yüz hareketlerini taklit ettiklerini göstermişlerdir. Bir başka araştırmada ise Meltzoff ve Moore (1977, 1983) yeni doğan bebeklerin, yetișkinlerin sunduğu yüz ifadeleri ve jestleri taklit edebildiklerini ve kopyalayabildiklerini rapor etmişlerdir. Yeni doğan bebeklerde rapor edilen tepkilerin taklit olarak nitelendirilip nitelendirilemeyeceğine dair alanyazında devam eden bir güncel tartışma olsa da bir diğer grup araştırmacı da (Young-Browne vd., 1977) bebeklerin erken dönemden itibaren (3 ay) mutlu, üzgün ve şaşkın yüz ifadelerini ayırt edebildiklerini bulgulamıșlardır. İlerleyen gelișimsel süreçlerde bebekler 4-8 ay arasında farklı yüz ifadelerine ait duyguları anlamaya ve yorumlamaya başlamakta, 9 ay civarında ise belirgin olmayan durumlarda ne yapmaları gerektiğini bulmak amacıyla annenin yüzünde, sesinde ve jestlerinde duygusal göstergeler aramaktadırlar (Snow \& McGaha, 2003). Bununla birlikte bebeklerin ilk bir yıllık gelişim süreci içerisinde ifade ettikleri duygular anneleri tarafından ayırt edilmekte, dolayısıyla bebekler annelerin yüz ifadelerine daha fazla yanıt vermeye başlamakta ve bu bilgileri kendi duygularını düzenlemek için kullanmaktadırlar (Wall, 2006). Bir diğer yönüyle ilk bir yıllık duygusal gelişim süreci içerisinde bebekler yabancı veya yeni bir deneyimin güvenli olup olmadığına karar vermek için yetişkinlerin yüz ifadelerini ve duygu durumlarını kullanarak çevrelerini yorumlamakta ve çocuklarda bu süreç sosyal referans alma olarak da adlandırılmaktadır (Wittmer \& Petersen, 2006).

Görme yetersizliğinden etkilenmiş çocukların görsel girdideki sınırlılıklardan ötürü duyguları anlama ve sosyal gelişimlerinde gecikmeler gözlenebildiği bazı araştırmacılar tarafından ifade edilmektedir (Alimovic, 2013; Lang vd., 2017; Lieber \& Umansky, 2004). Çünkü sosyal etkileşimler genellikle yüz ifadeleri gibi insanlar tarafından güç algılanan ipuçlarına dayanmaktadır (Hallahan \& Kauffman, 2006). Özellikle sosyal etkileşim değişimlerinde görme girdisi başka kişilerin yüz ifadelerini gözlemlemeye olanak sağlamakta ve bu açıdan önemli bir ipucu niteliği taşımakta iken, görme yetersizliğinden etkilenmiş çocuklar için bu durum önemli bir sinırlılığ meydana getirmektedir (Lieber \& Umansky, 2004). Yapılan araştırmalarda görme yetersizliğinden etkilenmiş bebeklerin gören akranları gibi gülümsedikleri gözlenmekte ancak bu yüz ifadesinin ebeveynin sesine veya dokunsal oyunlarına yönelik ortaya çıktığı belirtilmektedir (Lewis, 1993). Lang ve diğerleri (2017) tarafından gerçekleştirilen bir çalışmada, 12-36 ay aralığında olan görme yetersizliğinden etkilenmiş bebeklerin sosyal 
duygusal gelişimleri çeşitli alt boyutlara göre (uyum, dikkat, oyun, akran ilişkileri gibi) değerlendirilmiştir. Bebeklerin görme düzeyleri azaldıkça başkaları ile ilgiyi paylaşma, çevreyi araştırma, akran ya da yetişkinle iletişimi başlatma, akranı ile taklit ve oyun becerilerinde daha fazla problemler yaşadıkları gösterilmiştir. Bununla birlikte bu araştırmanın diğer bulgularında, görme yetersizliğinden etkilenmiş bebeklerin empati gelişimi ve başkaları ile ilgiyi paylaşma becerilerinde de güçlükler sergiledikleri vurgulanmıştır. Alimovic (2013) ise bir çalışmasında 4-11 yaşları arasındaki görme yetersizliğinden etkilenmiş çocukların gören çocuklara oranla daha fazla duygusal problem yaşadıklarını ve sosyal becerilerde sınırlılıklar sergilediklerini göstermiştir. Bunun yanı sıra görme yetersizliğinden etkilenmiş çocukların okul döneminde de benzer problemler sergiledikleri Pinquart ve Pfeiffer (2012) tarafından yürütülen bir çalışmada da rapor edilmiştir. Araştırmacılar çalışmalarında, 6. ve 11. sınıf arasında eğitimine devam eden 158 görme yetersizliğinden etkilenmiş (60 ağır görme yetersizliğinden etkilenmiş, 98 az gören) öğrenci ile 158 gören öğrencinin psikolojik uyumlarını karşılaştırmıştır. Çalışmada görme yetersizliğinden etkilenmiş her bir öğrenci yaş, cinsiyet, yaşam şekilleri (aileyle beraber yaşama gibi) ve ailelerinin eğitim durumlarına dikkat edilerek gören öğrenciler ile eşleştirilmiştir. Çalışmanın sonuçları görme yetersizliğinden etkilenmiş öğrencilerin gören öğrencilere göre daha fazla duygu ve akran problemi yaşadıklarını, bununla birlikte gruplar arasında duygu problemlerinin yaşla birlikte artış gösterdiği kaydedilmiştir.

Diğer taraftan alanyazında bazı araştırmacılar yüz ifadelerinin birtakım bileşenlerinin doğuştan var olduğu görüşünü destekleyen çalışmalar rapor etmişlerdir (Galati vd., 2001; Galati vd., 2003; Peleg vd., 2009). Bu doğrultuda görme yetersizliğinden etkilenmiş çocukların yüz ifadelerinin gören akranlarıla benzer olduğunu gösteren çalışmalar da mevcuttur (Galati vd., 2001; Galati vd., 2003). Galati ve diğerleri (2001) görme yetersizliğinden etkilenmiş çocukların duygu durumlarına yönelik yüz ifadelerini incelemişlerdir. Araştırmada 6 ay ile 4 yaş aralığında olan 10 görme yetersizliğinden etkilenmiş çocuk ve 10 gören çocuk yer almıştır. Araştırmacılar, katılımcı çocukların planlanan davranışı kesintiye uğratma, yetişkinle olumlu etkileşim gibi yedi farklı durumla ilintili olarak yansıtmaları beklenen kızgın, mutlu gibi duygulara yönelik yüzlerinin kaş, göz ve ağız bölgelerine ilişkin (gözleri kapatma, yanakları şişirme, ağzı açma gibi) ifadelerini incelemişlerdir. Araştırmanın sonunda görme yetersizliğinden etkilenmiş çocukların gören akranlarına benzer yüz ifadeleri sergileyebildikleri belirlenmiştir. Benzer şekilde araştırmacılar daha büyük yaş grubu (8-11 yaş) görme yetersizliğinden etkilenmiş (10 çocuk) ve gören (10 çocuk) çocuklarla aynı çalışmayı tekrar etmişlerdir (Galati vd., 2003). Aynı kategorilerin kullanıldığı ve kodlamaların yapıldığı çalışmanın sonunda araştırmacılar, görme yetersizliğinden etkilenmiş ve gören çocukların duygusal yüz ifadelerinin benzer olduğunu tespit etmişlerdir. Araştırmanın bulguları doğrultusunda, görme yetersizliğinden etkilenmiş çocukların özellikle gözlerini kapatma, ağzını açma ve baş hareketleri yapma gibi bazı özellikli yüz ifadelerini daha fazla sergiledikleri gözlemlenirken, gören çocukların sosyal açıdan olumsuz duygularını saklamak için daha çok gülümsedikleri belirtilmiştir (Örneğin, negatif durumlarda gören çocukların görme yetersizliğinden etkilenmiş akranlarına oranla daha fazla gülümsemeleri gibi). Peleg ve diğerleri (2009) bir çalışmalarında görme yetersizliğinden etkilenmiş bireyler ile gören yakınlarının yüz ifadelerini karşılaştırmışlardır. Araştırmanın katılımcı grubunu 24 görme engelli birey (150 yaş) ile onların yakını olan 30 kişi (1-70 yaş) oluşturmuştur. Çalışmada katılımcıların düşünme ve konsantre olma, üzgün, kızgın, iğrenme, mutluluk ve şaşkınlık yüz ifadelerini tespit etmek amacıyla görüşmeler yapılmıştır. Katılımcıların yüz ifadeleri iki farklı şekilde görüşmeler aracılığıyla değerlendirilmiştir. İlk olarak araştırmacı, katılımcı kişilerin yüz ifadelerinin anlık bir şekilde ortaya çıkarılabilmesi için yüz ifadelerini ortaya çıkaracak hikâyeler anlatıp hisleri hakkında sorular yöneltmiştir. İkinci aşamada ise katılımcılardan geçmişte yoğun bir şekilde yaşadığı bir duygu üzerine deneyimini paylaşması istenilmiştir. Araştırmanın sonucuna göre katılımcılar tarafından sergilenen yüz ifadeleri arasında benzerlikler tespit edilmiştir. Dolayısıyla araştırmacılar, çalışmalarının sonunda duygu durumlarıyla ilintili yüz ifadelerinin doğuştan geldiğini destekleyen görüşlerini vurgulamışlardır. Alanyazında bu araştırmaların aksine Tröster ve Brambring (1992) bir çalı̧̧masında 9-12 ay arasında görme yetersizliğinden etkilenmiş ( 5 çocuk 9 aylık, 17 çocuk 12 aylık) ve gören (23 çocuk 9 aylık, 24 çocuk 12 aylık) bebeklerin duygusal ve sosyal gelişimlerini karşılaştırmıştır. Araştırmanın verileri anneyle yapılan yarı yapılandırılmış görüşmeler ve anne-bebek etkileşimine dayalı oyun gibi etkinliklerde bebeğin yüz ifadelerinin gözlemlenmesi ile elde edilmiştir. Araştırmanın bulgularında, görme yetersizliğinden etkilenmiş bebeklerin gören akranlarına oranla daha sınırlı yüz ifadeleri sergiledikleri ve daha az duygu ifadeleri tepkileri gösterdikleri rapor edilmiştir.

Pek çok araştırmacı tarafından duyguların sosyal bağlamlarda geliştiği ifade edilmektedir (Hyson, 2004). Örneğin; gülmek, gören bireylerde kendiliğinden gelişen bir sosyal tepki iken, görme yetersizliğinden etkilenmiş bireyler için aynı durum söz konusu olmayabilmektedir (Hallahan \& Kauffman, 2006). Görme yetersizliğinden etkilenmiş çocuklarda diğer bireylerin yüz ifadelerini ve beden dilini okuma becerilerindeki sınırlılıklar, bu çocukların iletişim becerilerinin de dolaylı olarak etkilenmesine neden olabilmektedir (Wolffe, 2000). Bu 
doğrultuda, duygu ifadeleri sosyal ilişkileri etkilemekte, bu nedenle de duygusal gelişim ile sosyal gelişim arasında bir bağ bulunduğu düşünülmektedir (Hall vd., 1986; Howard vd., 2005). Erken çocukluk döneminde çocukların akranlarıyla sosyalleşmesi, iletişim kurması ve uyumlu oyun oynama becerilerini edinmesi önemli dönüm noktalarındandır (Junn \& Boyatzis, 2009). Bu nedenle çocukların duygusal olarak iyi gelişmiş olmaları, onların okula uyum sağlamalarını desteklerken; çocukların ciddi duygusal problemler yaşamaları ise okul başarısını olumsuz yönde etkilemektedir (Ahn, 2005). Okul öncesi dönemde çocuklar bilişsel ve dil becerilerinin gelişimine paralel olarak kendilerinin ve diğer bireylerin duygularını anlamak için daha yetkin (Lieber \& Umansky, 2004) bireyler haline gelmekle birlikte, bu dönem genel olarak akran etkileşimi ve arkadaşlık dönemi olarak nitelendirilmektedir (Stanton-Chapman \& Raver, 2009). Bu dönemde sosyal beceriler akran kabulü için önemlidir ancak ağır görme yetersizliğinden etkilenmiş ve az gören çocukların bu alanda sergiledikleri güçlükler (Smith, 2001) ve sosyal becerilerdeki sınırlılıklarından dolayı gören akranları tarafından kabul görmeyebilmektedirler (Culatta \& Tompkins, 1999). Nitekim, görme yetersizliği olan çocukların akran kabulü sorunu veya bir uzantısı olan yalnız oyun oynama ile ilgili araştırmalardan birinde Crocker ve Orr (1996), okul öncesi dönemde görme yetersizliğinden etkilenmiş çocuklar (ortalama 54 aylık, 9 katılımcı çocuk) ve gören çocukların (ortalama 49 aylık, 9 katılımcı çocuk) sosyal becerilerini değerlendirmişlerdir. Araştırmada görme yetersizliğinden etkilenmiş çocukların gören akranlarının yanında tek başına oyun oynama eğiliminde olduklarını ve diğerlerinin oyuna katılma önerilerini ise göz ardı ettiklerini belirtmişlerdir. Görme yetersizliği olan okul öncesi dönem çocuklarda akranlarla sosyal uyumun bir göstergesi olan oyun becerilerinin farklılaştı̆ı (Aslan vd., 2015) benzer olarak ebeveyn çocuk etkileşimininde ortak dikkat, katılım, duygusal durum gibi sosyal etkileşim alanlarında da görme yetersizliği olan çocukların anneleriyle olan etkileşimlerinde gören akranlarından düşük puanlar aldıkları rapor edilmektedir (İtiş \& Özdemir, 2019). Alanyazında daha büyük yaş gruplarıyla yapılan çalışmalarda da görme yetersizliğinden etkilenmiş ve gören çocukların sosyal becerileri karşılaştırılmış ve görme yetersizliğinden etkilenmiş çocukların sosyal becerilerinin gören akranlarına oranla sınırlılıklar sergiledikleri (Demir \& Özdemir, 2016a; Özkubat \& Özdemir, 2012) ve problem davranışlarının da daha yüksek olduğu rapor edilmiştir (Demir \& Özdemir, 2016b).

Özetle, yüz ifadeleri evrenseldir ve duyguların etkili bir şekilde diğer insanlarla paylaşılmasını sağlamaktadır (Snowden vd., 2006). Alanyazında araştırmacılar doğumdan itibaren hangi duyguların mevcut olduğu konusunda ikiye ayrılmakta, bazı araştırmacılar mutlu, meraklı, şaşkın, korkmuş, kızgın, üzgün ve iğrenmiş gibi temel duyguların doğuştan var olduğunu (Johnson vd., 1982) bazı araştırmacılar ise duyguların memnuniyet ile sıkıntılı olmak arasında iki temel duruma dayanarak (Lewis, 2008) geliştiğini ifade etmektedirler. Yüz ifadelerinin bazı bileşenlerinin doğuştan var olduğunu gösteren araştırmalar görme yetersizliğinden etkilenmiş kişilerin yüz ifadelerinin gören akranlarıyla benzer olduğunu rapor etmiştir (Galati vd., 2001; Galati vd., 2003; Peleg vd., 2009). Oysaki pek çok araştırmacı tarafından görme yetersizliğinden etkilenmiş çocukların görsel girdiden yoksun olmaları nedeniyle yüz ifadelerini okumada sınırlılıklar sergiledikleri (Wolffe, 2000) ve duyguları anlama ve sosyal gelişimlerinde gecikmeler olduğu ifade edilmektedir (Alimovic, 2013; Lang vd., 2017; Lieber \& Umansky, 2004). Diğer taraftan bireylerin duygusal ifadeler aracıllğıyla diğer kişilerin duygu, düşünce ve isteklerinin farkına vardıklarını ve bu sayede hızlı bir şekilde sosyal etkileşimlerini düzenledikleri belirtilmektedir (Keltner \& Haidt, 1999). Bununla birlikte duygusal olarak iyi gelişmiş çocuklarda okula uyum sağlama olanağ1 artarken, ciddi duygusal problemleri olan çocuklar ise okul başarısı konusunda risk altındadırlar (Ahn, 2005). Bu açıdan okul öncesi dönemde görme yetersizliğinden etkilenmiş çocukların duygu ifadeleri tepkilerinde gecikmelerin veya farklılıkların olup olmadığını tespit etmek, görsel algının duygu ifade tepkilerini ne derece etkilediğini belirlemek açısından önemlidir. Görme yetersizliğinden etkilenmiş çocukların görme düzeylerinin duygu ifade tepkilerine etkisini belirlemek gecikme sergileyen çocukların erken dönemden itibaren desteklenmelerine olanak sağlayarak bu konuda bir rehber olabileceği düşünülebilir. Bu kapsamda bu araştırmada, ağır görme yetersizliğinden etkilenmiş çocuklar, az gören çocuklar ve gören çocukların duygu ifadeleri tepkilerinin karşılaştırılması amaçlanmıştır.

\section{Yöntem}

\section{Araştırma Deseni}

$\mathrm{Bu}$ araştırmada az gören, ağır görme yetersizliği olan ve gören çocukların akranın sergilediği üzgün ve mutlu duygu ifadesine verdikleri tepkiler incelenmiştir. Araştırma, nicel araştırma yöntemlerinden biri olan ilişkisel tarama modeli ile desenlenmiştir. Bu model iki değişsen arasındaki ilişkiyi incelemeye ve değişkenler arasındaki ilişkinin gücü ile yönünü belirlemeye olanak sağlamaktadır (Franzese \& Iuliano, 2019). 


\section{Katılımcılar}

Araştırmanın katılımcılarını 4-6 yaş aralığında olan 20 görme yetersizliği olan (10 az gören, 10 ağır görme yetersizliğinden etkilenen) ve 20 gören çocuk oluşturmuştur. Araştırmada, ölçüt örnekleme yöntemi kullanılmıştır. Ölçüt örnekleme yöntemi gözlem için belirlenen ölçütü karşılayan örneklemlerle gerçekleştirilmektedir (Büyüköztürk vd., 2014). Katılımcılar, Ankara ilinde Milli Eğitim Bakanlığına bağlı İlköğretim Okulları, Görme Engelliler İlköğretim Okulları ve Özel Özel Eğitim Kurumlarına devam etmekte olan çocuklardır. Araştırmada katılımcı çocukların belirlenmesinde bazı ölçütler kullanılmıştır. Ölçütleri karşılayan çocuklar çalışmaya dâhil edilmiştir. Araştırmada uygulanan ölçütler az gören ve ağır görme yetersizliği olan çocuklar için sırasıyla; (a) 4-6 yaş aralığında olma, (b) üniversite hastaneleri veya devlet hastanelerinden doğuştan veya bir yaşına kadar ağır görme yetersizliği tanısı alma veya az gören tanısı almış olma (hafif, orta), (c) Ankara Gelişim Tarama Envanteri (AGTE) uygulama sonuçlarına göre dil bilişsel gelişim alanında gelişimsel yetersizlik sergilememe olarak belirlenmiştir. Dünya Sağlık Örgütü (DSÖ) tanımlarına bağlı olarak görme yetersizliği uzak görme ve yakın görme olarak ele alınmakta ve görme keskinliği 6/12'den kötü ise hafif, 6/18'den kötü ise orta, 6/60'dan kötü ise ağır, 3/60'dan kötü ise körlük olarak ifade edilmektedir (DSÖ, 2018). Gören çocuklarda ise ölçütler; (a) 4-6 yaş aralığında olma, (b) ailelerden ve öğretmenlerden alınan bilgiler doğrultusunda herhangi bir yetersizlik sergilememe, (c) Ankara Gelişim Tarama Envanteri (AGTE) uygulama sonuçlarına göre dil bilişssel gelişism alanında gelişimsel yetersizlik sergilememe ölçütleri dikkate alınmıştır. Araştırmada yer alan katılımcı çocukların demografik bilgilerine Tablo 1'de yer verilmiştir.

Tablo 1

Az Gören Çocuklar, Ăğır Görme Yetersizliği Olan Çocuklar ve Gören Çocukların Demografik Bilgileri

\begin{tabular}{lccccc}
\hline \multicolumn{1}{c}{} & \multicolumn{2}{c}{ Yaş (ay) } & \multicolumn{2}{c}{ Cinsiyet } \\
\hline Katılımcılar & $\bar{X}$ & $S S$ & $X_{\min }-X_{\max }$ & $\mathrm{K}$ ız $(N)$ & Erkek $(N)$ \\
\hline Az gören & 65.10 & 2.54 & $52-76$ & 5 & 5 \\
Ağı̈r görme yetersizliği olan & 66.70 & 2.43 & $55-77$ & 1 & 9 \\
Gören & 65.90 & 1.95 & $52-78$ & 8 & 12 \\
\hline
\end{tabular}

\section{Veri Toplama Araçları}

Çalışmada katılımcı çocukların gelişimsel seviyelerini belirlemek amacıyla Savaşır ve diğerleri (1994) tarafından geliştirilen AGTE kullanılmıştır. AGTE, 0-6 yaş aralığında olan çocukların gelişimlerini ailelerden alınan bilgiler doğrultusunda değerlendirmeye olanak sağlamaktadır. AGTE, Dil-Bilişsel, İnce Motor, Kaba Motor, Sosyal Beceri-Özbakım olmak üzere 4 alt test ve 154 maddeden oluşmaktadır. Değerlendirmeler sırasında çocuğun yaş diliminden başlanarak aileye sorular yöneltilmekte ve aileler sorulara ilişkin Evet-Hayır-Bilmiyorum şeklinde yanıtlayabilmektedir Araştırmacılar tarafından AGTE öncelikle Türkçe' ye çevrilerek envanterde yer alacak maddelerin kültüre uygunluğu açısından anneler ile görüşmeler yapılmıştır. Görüşmelerden elde edilen maddelerden bir form oluşturulup annelere uygulanarak envanterin son hali oluşturulmuştur. AGTE'nin iç geçerlik analizleri 0-1, 1-3.5, 3.5-6 yaş gruplarında Cronbach Alpha katsayıları hesaplandığında iç tutarlılığın oldukça yüksek olduğu belirtilmiştir. AGTE test tekrar test uygulamaları sonuçları iç tutarlılı̆̆ın yaş gruplarına göre .99 , .98 ve .88 olduğunu göstermiştir (Savaşır vd., 1994).

Araştırmada az gören, ağır görme yetersizliği olan ve gören çocukların mutlu ve üzgün duygu ifadeleri tepkileri incelenmiştir. Katılımcı çocukların mutlu ve üzgün duygu ifadelerine verdikleri tepkiler için araştırmacılar tarafından geliştirilen duygu durum tepkileri gözlem protokolüne yer verilmiştir. Katılımcı çocukların verdikleri tepkileri kodlamak için yedi davranış kategorisi kullanılmıştır. Kategoriler, Ahn (2003) ve Demorat'ın (1998) çalışmalarında kullanılan gözlem kategorileri uyarlanarak oluşturulmuştur.

Çalışmada, araştırmacılar tarafından görme yetersizliğinden etkilenmiş çocukların görme girdilerindeki sınırlılıklar göz önünde bulundurularak materyaller önceden belirlenmiştir. Mutlu duygu ifade tepkilerini değerlendirmek amacıyla çocukların birlikte çalışarak ve görev paylaşarak yapabilecekleri dokunsal bir yapboz verilmiştir. Yapboz, kısa uçlarının iki farklı doku ve renklerden oluşturularak yapıldığı dikdörtgen şeklinde olan tahtalardan oluşmaktadır. Yapbozun tamamlanabilesi için görme yetersizliği olan çocuklarda aynı doku veya gören çocuklarda aynı renkten olan şeklin artarda gelmesi gerekmektedir. Araştırmanın ikinci kısmında ise 1şıklı, sesli bir oyuncak çaydanlık kullanılarak çocukların üzgün duygu ifade tepkileri gözlemlenmiştir. 


\section{Veri Toplama Süreci}

$\mathrm{Bu}$ araștırmada katılımcı çocuklarla iki farklı gözlem süreci yürütülmüştür. Gözlemler çocukların ikili akran etkileşimleri aracıllğıyla kaydedilmiştir. İkili etkileşimler, çocukların birbirlerine yönelttikleri süreğen tepkilerin gözlemlenmesinde sıklıkla kullanılan bir tekniktir (Garner vd., 1997; McLoyd, 1983). İkili akran etkileşimlerinin ardından katılımcı çocukların, akranının sergilediği mutlu ve üzgün duygu durumlarına verdikleri tepkiler kaydedilmiştir. Araştırmanın veri toplama sürecinde öncelikli olarak okul yönetimleri bilgilendirilmiş ve ailelerle birebir görüşmeler gerçekleştirilmiş̧ir. Araştırmaya katılmaya gönüllü olan ailelerin izinleri doğrultusunda çocukların çalışmaya isteyerek katılım sağlamasına özen gösterilmiştir. Aday katılımcı çocukların çalışmada yer alabilmeleri için AGTE uygulanarak çocukların gelişimsel seviyeleri belirlenmiştir. Bu amaçla katılımcı çocukların ebeveynleriyle yüz yüze görüşmeler yapılmıștır. Ailelere AGTE'de yer alan gelișim alanlarına ilişkin sorular sorularak AGTE uygulamaları tamamlanmıştır. Görüşmeler sonucunda dil bilişsel gelişim alanında gelişimsel gecikme sergilemeyen ve araştırmanın katılımcı ölçütlerini taşıyan çocuklar katılımcı gruplarına dâhil edilmiştir. Araştırmada aday katılımcılar belirlenirken beş görme yetersizliği olan çocuğun dil ve motor gelişim alanlarında gelişimsel yetersizlikler sergilediklerinin tespit edilmesi nedeniyle katılımcı gruplarına bu çocuklar dâhil edilememiş̧ir.

Doğal gözlemler, çok uzun gözlem süreci gerektirmesi nedeniyle bilimsel araştırmalarda uygulanması son derece güç ve etkili kullanımı olası görünmeyen uygulamalardır. Doğal gözlemlere karşın yarı doğal gözlemler, hedef tepkileri gözlemleyebilmek için ekolojik geçerliğin sağlandığı çevresel koşullarda yürütülür. Yarı doğal gözlemlerde araştırmacı gözlememek istediği tepkinin ortaya çıkmasını sağlayacak çevresel ve etkileşimsel koşulları düzenler (Heyman vd., 2014). Bu araştırmada bu gözlem tekniği çerçevesinde yarı doğal gözlem tekniği uygulanmış, katılımcı çocukların başkalarının duygu durumlarına verdikleri tepkileri gözlemlemeye olanak sağlayacak etkileşimsel düzenlemeler gerçekleştirilmiştir. Ekolojik geçerlik doğrultusunda uygulamalar, çocukların eğitim aldıkları Milli Eğitim Bakanlığına bağlı Görme Engelliler İlköğretim Okulları, İlköğretim Okulları veya Özel Özel Eğitim Kurumlarında yer alan serbest oyun köşelerinde gerçekleştirilmiştir. Serbest oyun köşeleri halı ile kaplı ve aydınlık olan, çeşitli oyuncakların yer aldığı, katılımcı çocukların hali hazırda eğitim aldıkları ortamlar olması nedeniyle aşina oldukları ortamlardır. Serbest oyun köşeleri içerisinde çocukların oyuncaklarını koymak amacıyla kullanılan dolaplar ile yer minderleri de bulunmaktadır.

Araştırma tüm veri toplama sürecinde, serbest oyun köşelerine yerleştirilen ve dikkat çekmeyen kameralar aracılığıyla çocukların mutlu ve üzgün duygu ifadeleri tepkileri kayıt altına alınmıştır. Katılımcı çocukların mutlu ve üzgün duygu ifade tepkileri gözlem süreci 10'ar dakikalık kayıtlar olmak üzere toplam 20 dakika boyunca sürdürülmüştür. Araştırmada ilk olarak çocukların mutlu duygu ifade tepkileri ardından üzgün duygu ifade tepkileri gözlenmiştir. İki duygu durumu arasında oyuncaklarla oynayarak akıcı bir ara verilmesine dikkat edilmiştir.

\section{Mutlu Duygu İfade Tepkileri}

Araştırma kapsamında mutlu ve üzgün duygu ifadeleri tepkileri değerlendirilmiştir. Uygulamacı tarafindan her çocuk kendi akran grubunda yer alan bir çocuk ile eşleştirilmiştir. Bu doğrultuda katılımcı olarak belirlenen çocuklar bir akranıyla eşleştirilerek, oyun çiftleri oluşturulmuş ancak sadece katılımcı-hedef çocukların mutlu veya üzgün duygu ifade tepkileri gözlemlenmiştir. Uygulamacı katılımcı çocuklara anlaşılır, basit bir şekilde oyun bağlamını açıklamıştır. Mutlu duygu durumu bağlamında, uygulamacı görme yetersizliğinden etkilenen çocuk çiftlerine dokunsal bir yapbozu vererek, yapbozun parçalarını sırası ile ard arda koyarak, beraber çalışarak ve görevi paylaşarak tamamlamaları gerektiğini açıklamıştır. Yapbozun parçalarının aynı doku ve aynı renklerin art arda gelmesiyle oluşturulacağı konusunda bilgi vermiştir. Araştırmacı bu açıklamanın ardından çocuklarla örnek denemeler gerçekleştirmiştir. Katılımcı çocuklara, yapbozun tamamlanmasının ardından ortak bir görevi beraber başarıyla bitirmelerinden dolayı sırasıyla ödül kazanacakları söylenmiş ve ilk olarak kimin ödül kazanacağını açıklanmışır. Gözlem sürecinde araştırmacı katılımcı çocukların oyunlarına hiçbir müdahalede bulunmamıştır. Mutlu duygu durumu tepkilerine yönelik oyun sırasında tepkileri gözlemlenen hedef çocuğa, ilk olarak akranının ödül kazanacağı ardından da kendisinin ödül kazanacağı açıklanmıştır. Bu açıklamadan sonra çocuklar, ilk oyunu tamamladıklarında akrana ödülü verilmiştir. Katılımcı çocuğun akranıyla birlikte bir görevi başarmalarının ve akranın ödül almasının sonucunda sergilediği mutlu duygu ifadesine katılımcı çocuğun verdiği tepkiler kaydedilmiştir. Araştırmada mutlu duygu durumunun tamamlanmasının üzerinden 10 dakikalık bir zaman diliminin geçmesi ile üzgün duygu durumu gözlem oturumuna geçilmiştir. 


\section{Üzgün Duygu Ífade Tepkileri}

Araştırmanın ikinci kısmında katılımcı çocukların üzgün duygu ifade tepkileri değerlendirilmiştir. Aynı şekilde her çocuk kendi akran grubunda yer alan bir çocuk ile eşleştirilmiştir. Uygulamacı çocuklara yeni bir oyuncak getirdiğini ifade ederek oyuncağı sırayla oynayabileceklerini söylemiştir. Ardından ışıklı, sesli son derece ilgi çekici bir oyuncak çaydanlığı tepkileri gözlemlenen katılımcı çocuğa vermiștir. Hedef çocuğun oyuncak ile bir süre oynamasına, incelemesine firsat verilmiştir. Çocuk oyuncağ incelerken uygulamacı oyuncağın çok ilgi çekici bir oyuncak olduğunu belirtmiştir. Oyuncakla oynama sırası akranına geldiğinde ise sürenin bittiği belirtilerek oyuncak akrana verilmemiştir. Bu durum akranın üzülmesine neden olmuştur. Akranının oyuncağı elde edememe durumunda sergilediği üzgün duygu ifadesine yönelik hedef çocuğun verdiği tepkiler kamera ile kayıt altına alınmıştır. Araştırma tamamlandıktan sonra akranın oyuncağı incelemesine firsat verilerek oyuncakla oynamasına izin verilmiştir.

\section{Verilerinin Kodlanması}

Araşıırmada, katılımcı çocukların akranıyla beraber işbirliği içinde ilk oyunu tamamlamalarının ardından, akranının ödül kazanması sonucunda sergilediği mutlu duygu ifadesine yönelik katılımcı çocuğun verdiği tepkiler kodlanmıştır. Üzgün duygu ifade tepkilerinde ise katılımcı çocukların akranın yeni bir oyuncağı elde etme şansını kaçırdıkları için üzgün oldukları durumda sergiledikleri tepkiler kodlanmıştır.

Araştırmada mutlu ve üzgün duygu ifadelerine yönelik katılımcı çocukların verdikleri tepkiler yedi farklı kategoride; Görmezden Gelme "G", Fiziksel Yakınlık "F", Uyumlu Tepki "E", Dikkati Dağıtma "D", Tepki Vermeden Dikkati Yöneltme "DY", Uyumsuz Tepki "U" ve Fiziksel Heyecan Tepkisi "FT" kategorilerinde kodlanmıştır. Kodlama kategorinin tanımları sırasıyla şu şekildedir:

1. Görmezden Gelme: Akranın sergilediği duyguya, çocuğun herhangi bir tepki vermemesi, ilgilenmemesi, kendi oyun aktivitesine hiçbir şey olmamış gibi devam etmesi davranışlarıdır.

2. Fiziksel Yakınlık: Çocuğun akranına sarılması, koluna veya vücuduna dokunması, ona doğru bakışlarını veya başını çevirerek yanına doğru gelmesi davranışlarıdır.

3. Uyumlu Tepki: Çocuğun, akranının sergilediği duygu ifadesine karşlık olarak aynı veya uyumlu duygu ifadesini sergilemesi davranışlarıdır. Sergilenen üzgün duygu ifadesine karşllık çocuğun kaşlarını kaldırması, gözlerini kısması, yanaklarını şişirmesi, dudak çizgilerini aşağı doğru indirmesi, sesini inceltip ve kısık ve yavaş bir şekilde konuşması davranışları kodlanmıştır. Mutlu duygu ifadesine çocuğun gözlerini büyük, yuvarlak, parlak bir şekilde açması, dudaklarını açarak veya kapalı bir şekilde gülümsemesi, dudak çizgilerini yukarı kaldırması ve yüksek ses tonuyla cevap vermesi davranışları kodlanmıştır.

4. Dikkati Dağıtma: Çocuğun akranın dikkatini başka bir etkinliğe veya oyuna çekme davranışlarıdır (Örneğin; akranı yeni oyuncakla oynayamadığında çocuğun akranına "Haydi sınıfa gidelim." deme durumu gibi).

5. Tepki Vermeden Dikkati Yöneltme: Çocuğun sergilenen duygu durumu karşısında duraksaması, hiç tepki vermeden çevresini dinlemesi, dikkat kesilmesidir.

6. Uyumsuz Tepki: Çocukların akranının verdiği tepkiye uyumsuz tepki vermesi, akranı üzgünken gülümseme, mutluyken dudaklarını büzmesi davranışlarıdır.

7. Fiziksel Heyecan Tepkisi: Çocukların akranının mutlu durumuna uygun el çırpma, zıplama, omuzlarını oynatma; üzgün durumuna ilişkin kollarını hızlıca aşağı indirme davranışlarıdır. Bu kategoride çocuk akranıyla dokunsal bir temas kurmadan tepkiler vermekte ve bu anlamda fiziksel yakınlık kategorisinden farklılaşmaktadır.

Katılımcı görme yetersizliği olan ve gören çocuklardan elde edilen mutlu ve üzgün duygu ifadeleri tepkileri bütüncül zaman aralığı kayıt tekniği kullanılarak ve gözlem süreci 10'ar saniyelik zaman aralıklarına bölünerek kodlanmıştır. Oyun sürecinde katılımcı çocukların duygu ifade tepkilerini süreğen bir şekilde sergilemeleri, çocukların tepkilerinin anlık değişmemesi nedeniyle bütüncül zaman aralığı tekniği uygulanmıştır. Kodlama sürecinde katılımcı çocukların ilgili duygu ifadesine yönelik verdikleri tepkiler 10 saniye boyunca izlenmiştir. Çocukların 10 saniye boyunca sergilediği kategori not edilmiştir. 


\section{Uygulama Güvenirliği}

Araştırmanın uygulama güvenirliği verileri çocukların duygu ifadeleri tepkileri video kayıtlarının \%30’u seçkisiz atamayla belirlenerek bir uzman tarafından videolar izlenerek belirlenmiştir. Araştırmada uygulama güvenirliğini belirleyebilmek amacıyla bir Uygulama Güvenirlik Formu oluşturulmuştur. Form oluşturulurken mutlu ve üzgün duygu ifade tepkileri olarak iki temel başlık altında maddeler ifade edilmiştir. Mutlu ve üzgün duygu ifade tepkileri kapsamında uygulamacının gözlem sürecinde katılımcılar ile tanışma, katılımcılara süreci basit ve anlaşılır bir şekilde ifade etme, katılımcı çocuğun akranıyla beraber oyunu sırasında sürece müdahalede bulunmama, katılımcı çocukların duygu ifade tepkileri sergilemeleri konusunda herhangi bir yönlendirme veya müdahalede bulunmama şeklindedir. Görme engellilerin eğitimi alanında yüksek lisansını tamamlamış bir uzman tarafından videolar izlenerek sürecin işleyişi form üzerine kodlanmıștır. Araştırmada hesaplamalar için [(Gözlenen Uygulamacı Davranışı / Planlanan Uygulamacı Davranışı) x 100] formülü kullanılmıştır (DiGennaro vd., 2007). Araştırmanın uygulama güvenirliği \%94.44 olarak belirlenmiştir.

\section{Gözlemciler Arası Güvenirlik}

Araştırmanın gözlemciler arası güvenirlik verileri katılımcı çocukların mutlu ve üzgün duygu ifadeleri tepkileri kodlanarak hesaplanmıştır. Araştırmaya katılan 40 çocuktan mutlu duygu ifade tepkilerinde toplam 40 video kaydı, üzgün duygu ifade tepkilerinde toplam 40 video kaydı alınmıştır. Çalışmada seçkisiz atamayla belirlenen, her iki katılımcı grubu eşit sayıda temsil eden ve kayıtların \%30'unu oluşturan videolarda gözlemciler arası güvenirlik verileri hesaplanmıştır. Toplamda gözlemciler arası güvenirlik hesaplamalarında kullanılan 24 video kaydının 12'si gören çocukların 12'si ise de görme yetersizliği olan çocukların verileridir ve mutlu ve üzgün duygu durumları arasında eşit dağılım yapılmıştır. Araştırmanın tüm verileri ile beraber gözlemciler arası güvenirlik hesaplamaları için araştırmanın ikinci yazarı tarafından iki gözlemciye eğitim verilmiştir. Eğitimin ilk aşamasında gözlemciler, gözlem bağlamı ve gözlemlenecek davranışlar hakkında genel olarak bilgilendirilmiştir. İkinci aşamada ise araştırma amacı doğrultusunda geliştirilen kodlama rehberi kullanılarak (a) kodlama işlem süreci ayrıntılı olarak tanımlanmış, (b) kod kategorileri arasındaki ayrım açık olarak tanımlanmış ve (c) kod kategorilerinin ayırt edici örnekleri gösterilmiştir. Eğitimlerin ardından kodlamalar tamamlanmıştır. Araştırmada hesaplamalar için [Görüş Birliği / (Görüş Birliği + Görüş Ayrılığı) x 100] formülü kullanılmıştır (Kazdin, 1982). Araştırmada, bu formüle göre gözlemciler arası güvenirlik mutlu duygu ifadesinde \%83.33, üzgün duygu ifadesinde \%85.41 olarak belirlenmiştir.

\section{Verilerin Analizi}

Araştırmada elde edilen veriler SPSS 20 programı kullanılarak analiz edilmiştir. Katılımcı çocukların mutlu ve üzgün duygu ifade tepkilerinin dağılımını belirlemeye yönelik yapılan normallik testleri sonucunda verilerin parametrik testlerin varsayımlarını karşılamadığı tespit edilmiştir. Araştırmada ilk olarak katılımcı çocukların tepkileri 20 görme yetersizliği olan ve 20 gören çocuk olmak üzere iki grupta Mann Whitney U testi kullanılarak analiz edilmiştir. Çocukların görme düzeylerinin duygu ifade tepkileri ile ilişkisinin derinlemesine incelenebilmesine amacıyla katılımcı çocuklar 10 az gören, 10 ağır görme yetersizliği olan ve 20 gören çocuk olarak üç grupta ele alınarak Kruskal Wallis testi uygulanmıştır. Kruskal Wallis testi sonuçlarına yönelik araştırmada anlamlı çıkan kategorilerin hangi grubun lehine olduğunu belirleyebilmek amacıyla post hoc (DunnBonferroni) testi sonuçları değerlendirilmiştir.

\section{Bulgular}

Araştırmada görme yetersizliği olan ve gören çocukların akranıyla birlikte bir oyunu tamamladıklarında, akranının kendi sırası gelip pekiştireç alarak mutlu olduğu durumda ve akranının sırası gelip de oyuncağı elde edemediği için üzgün olduğu durumda sergilenen duygu ifadeleri karşısında gösterdikleri duygu tepkileri karşılaştırılmıştır.

\section{Katılımcı Çocukların Mutlu Duygu İfade Tepkilerinin Karşılaştırılması}

Çalışmanın katılımcı grubunda yer alan görme yetersizliğinden etkilenmiş çocuklar ve gören çocukların sergiledikleri mutlu duygu ifade tepkileri Mann Whitney U testi uygulanarak incelenmiş, sonuçlar Tablo 2'de verilmiştir.

Çalışmanın katılımcı grubunda yer alan farklı görme düzeylerine sahip çocukların (az gören, ağır görme yetersizliği olan ve gören çocuklar) mutlu duygu ifade tepkilerini belirlemek amaciyla Kruskal Wallis testi (Tablo 3) uygulanmıştır. 
Tablo 2

Mann Whitney U Testi Mutlu Duygu Ifade Tepkileri Sonuçları

\begin{tabular}{|c|c|c|c|c|c|c|c|c|c|}
\hline Bağımlı değişken & Gruplar & $N$ & $S S$ & Sira ort. & Sira top. & $Z$ & $M$ & $U$ & $p$ \\
\hline G & $\begin{array}{l}\text { Görme yetersizliğinden etkilenmiş } \\
\text { Gören }\end{array}$ & $\begin{array}{l}20 \\
20\end{array}$ & $\begin{array}{l}1.33 \\
.52\end{array}$ & $\begin{array}{l}29.20 \\
11.80\end{array}$ & $\begin{array}{l}584.00 \\
236.00\end{array}$ & -5.032 & 1.00 & 26.00 & $.000 * * *$ \\
\hline $\mathrm{F}$ & $\begin{array}{l}\text { Görme yetersizliğinden etkilenmiş } \\
\text { Gören }\end{array}$ & $\begin{array}{l}20 \\
20\end{array}$ & $\begin{array}{l}.00 \\
.60\end{array}$ & $\begin{array}{l}16.00 \\
25.00\end{array}$ & $\begin{array}{l}320.00 \\
500.00\end{array}$ & -3.354 & .00 & 110.00 & $.001 * *$ \\
\hline $\mathrm{E}$ & $\begin{array}{l}\text { Görme yetersizliğinden etkilenmiş } \\
\text { Gören }\end{array}$ & $\begin{array}{l}20 \\
20\end{array}$ & $\begin{array}{l}1.37 \\
.82\end{array}$ & $\begin{array}{l}12.78 \\
28.23\end{array}$ & $\begin{array}{l}255.50 \\
564.50\end{array}$ & -4.327 & 2.00 & 45.50 & $.000 * * *$ \\
\hline $\mathrm{D}$ & $\begin{array}{l}\text { Görme yetersizliğinden etkilenmiş } \\
\text { Gören }\end{array}$ & $\begin{array}{l}20 \\
20\end{array}$ & $\begin{array}{l}.00 \\
.00\end{array}$ & $\begin{array}{l}20.50 \\
20.50\end{array}$ & $\begin{array}{l}410.00 \\
410.00\end{array}$ & .000 & .00 & 200.00 & 1.000 \\
\hline DY & $\begin{array}{l}\text { Görme yetersizliğinden etkilenmiş } \\
\text { Gören }\end{array}$ & $\begin{array}{l}20 \\
20\end{array}$ & $\begin{array}{l}.52 \\
.00\end{array}$ & $\begin{array}{l}22.00 \\
19.00\end{array}$ & $\begin{array}{l}440.00 \\
380.00\end{array}$ & -1.777 & .00 & 170.00 & .076 \\
\hline $\mathrm{U}$ & $\begin{array}{l}\text { Görme yetersizliğinden etkilenmiş } \\
\text { Gören }\end{array}$ & $\begin{array}{l}20 \\
20\end{array}$ & $\begin{array}{l}.22 \\
.00\end{array}$ & $\begin{array}{l}21.00 \\
20.00\end{array}$ & $\begin{array}{l}420.00 \\
400.00\end{array}$ & -1.000 & .00 & 190.00 & .317 \\
\hline FT & $\begin{array}{l}\text { Görme yetersizliğinden etkilenmiş } \\
\text { Gören }\end{array}$ & $\begin{array}{l}20 \\
20\end{array}$ & $\begin{array}{l}.00 \\
.44\end{array}$ & $\begin{array}{l}18.00 \\
23.00\end{array}$ & $\begin{array}{l}360.00 \\
460.00\end{array}$ & -2.360 & .00 & 150.00 & $.018 *$ \\
\hline
\end{tabular}

Not: $\mathrm{G}=$ görmezden gelme; $\mathrm{F}$ = fiziksel yakınlık; $\mathrm{E}=$ uyumlu tepki; $\mathrm{D}=$ dikkati dağıtma; $\mathrm{DY}=$ tepki vermeden dikkati yöneltme; $\mathrm{U}=$ uyumsuz tepki; FT = fiziksel heyecan tepkisi.

$* p<.05 ; * * p<.01 ; * * * p<.001$.

Tablo 2'de yer alan sonuçlar incelendiğinde görme yetersizliğinden etkilenmiş çocuklar ve gören çocukların mutlu duygu ifade tepkileriyle ilişkili Görmezden Gelme $(U=26.00, z=-5.032, p<.001)$, Fiziksel Yakınlık $(U=110.00, z=-3.354, p<.01)$, Uyumlu Tepki $(U=45.50, z=-4.327, p<.001)$ ve Fiziksel Heyecan Tepkisi $(U=150.00, z=-2.360, p<.05)$, kategorilerinde anlamlı bir farklılık gösterdiği görülmüştür.

Tablo 3

Kruskal Wallis Testi Mutlu Duygu Iffade Tepkileri Sonuçları

\begin{tabular}{|c|c|c|c|c|c|c|c|}
\hline Bağımlı değişken & Gruplar & $N$ & $S S$ & Sira ort. & $M$ & $x^{2}$ & $p$ \\
\hline \multirow[t]{3}{*}{ 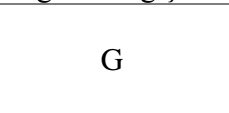 } & Az Gören & 10 & 1.64 & 25.90 & 1.00 & 27.14 & $.000 * * *$ \\
\hline & A ̆ğ1r & 10 & .51 & 32.50 & & & \\
\hline & Gören & 20 & .52 & 11.80 & & & \\
\hline \multirow{3}{*}{$\mathrm{F}$} & Az Gören & 10 & .00 & 16.00 & .00 & 11.25 & $.004 * *$ \\
\hline & Ağgr & 10 & .00 & 16.00 & & & \\
\hline & Gören & 20 & .60 & 25.00 & & & \\
\hline \multirow{3}{*}{$\mathrm{E}$} & Az Gören & 10 & 1.71 & 17.25 & 2.00 & 21.86 & $.000 * * *$ \\
\hline & Ağır & 10 & .31 & 8.30 & & & \\
\hline & Gören & 20 & .82 & 28.23 & & & \\
\hline \multirow{3}{*}{$\mathrm{D}$} & Az Gören & 10 & .00 & 20.50 & .00 & .00 & 1.000 \\
\hline & Ağgr & 10 & .00 & 20.50 & & & \\
\hline & Gören & 20 & .00 & 20.50 & & & \\
\hline \multirow{3}{*}{ DY } & Az Gören & 10 & .63 & 21.10 & .00 & 3.72 & .155 \\
\hline & Ağır & 10 & .42 & 22.90 & & & \\
\hline & Gören & 20 & .00 & 19.00 & & & \\
\hline \multirow{3}{*}{$\mathrm{U}$} & Az Gören & 10 & .00 & 20.00 & .00 & 3.00 & .223 \\
\hline & A ̆ğ1r & 10 & .31 & 22.00 & & & \\
\hline & Gören & 20 & .00 & 20.00 & & & \\
\hline \multirow{3}{*}{ FT } & Az Gören & 10 & .00 & 18.00 & .00 & 5.57 & .062 \\
\hline & Ağgrr & 10 & .00 & 18.00 & & & \\
\hline & Gören & 20 & .44 & 23.00 & & & \\
\hline
\end{tabular}

Not: $\mathrm{G}=$ görmezden gelme; $\mathrm{F}$ = fiziksel yakınlık; $\mathrm{E}=$ uyumlu tepki; $\mathrm{D}=$ dikkati dağıtma; $\mathrm{DY}=$ tepki vermeden dikkati yöneltme; $\mathrm{U}=$ uyumsuz tepki; FT = fiziksel heyecan tepkisi.

$* p<.05 ; * * p<.01 ; * * * p<.001$. 
Tablo 3 incelendiğinde, az gören, ağır görme yetersizliği olan ve gören çocukların mutlu duygu ifade tepkilerinin Görmezden Gelme $\left(\chi^{2}=27.14, p<.001\right)$, Fiziksel Yakınlık $(\chi 2=11.25, p<.01)$ ve Uyumlu Tepki $(\chi 2=21.86, p<.001)$ kategorilerinde anlamlı bir farklılık gösterdiği görülmüştür. Gruplar arasında gözlemlenen anlamlı farkın hangi grubun lehine olduğunu belirlemek amacıyla post hoc testi uygulanmıştır. Tabloda yer alan gruplar arası anlamlı farklılığa bakıldığında Görmezden Gelme kategorisinde az gören çocuklar ile gören çocuklar arasında anlamlı bir fark olduğu; bu farklılığın az gören çocukların lehine olduğu belirlenmiştir $(1>3, p=.001)$. Diğer gruplar incelendiğinden Görmezden Gelme kategorisinde ağır görme yetersizliği olan çocuklar ile gören çocuklar arasında anlamlı bir fark olduğu; bu farklılığın ağır görme yetersizliği olan çocukların lehine olduğu görülmüştür $(2>3, p=.000)$. Fiziksel Yakınlık kategorisi incelendiğinde gören çocuklar ile az gören çocuklar arasında anlamlı bir fark olduğu; bu farklılığın gören çocuklar lehine olduğu anlaşılmıştır $(3>1, p=.006)$. Fiziksel Yakınlık kategorisinde diğer gruplar arasındaki ilişkiye bakıldığında gören çocuklar ile ağır görme yetersizliği olan çocuklar arasında anlamlı bir fark olduğu; bu farklılığın gören çocuklar lehine olduğu anlaşılmıştır $(3>2, p$ $=.006)$. Uyumlu Tepki kategorisinde ise gören çocuklar ile ağır görme yetersizliği olan çocuklar arasında anlamlı bir fark olduğu; bu farklılığın gören çocuklar lehine olduğu belirlenmiştir $(3>2, p=.000)$. Uyumlu Tepki kategorisinde diğer gruplar açısından gören çocuklar ile az gören çocuklar arasında anlamlı bir fark olduğu; bu farklılığın gören çocuklar lehine olduğu anlaşılmıştır $(3>1, p=.012)$.

\section{Katılımcı Çocukların Üzgün Duygu İfade Tepkilerinin Karşılaştırılması}

Çalışmanın katılımcı grubunda yer alan görme yetersizliğinden etkilenmiş çocuklar ve gören çocukların sergiledikleri üzgün duygu ifade tepkileri Mann Whitney U testi uygulanarak incelenmiş, sonuçlar Tablo 4'de verilmiştir.

\section{Tablo 4}

Mann Whitney U Testi Üzgün Duygu Ífade Tepkileri Sonuçları

\begin{tabular}{|c|c|c|c|c|c|c|c|c|c|}
\hline Bağımlı değişken & Gruplar & $N$ & SS & Sira ort. & Sira top. & $Z$ & $M$ & $U$ & $p$ \\
\hline $\mathrm{G}$ & $\begin{array}{l}\text { Görme yetersizliğinden etkilenmiş } \\
\text { Gören }\end{array}$ & $\begin{array}{l}20 \\
20\end{array}$ & $\begin{array}{l}1.44 \\
.82\end{array}$ & $\begin{array}{l}26.03 \\
14.98\end{array}$ & $\begin{array}{l}520.50 \\
299.50\end{array}$ & -3.140 & 1.00 & 89.50 & $.002 * *$ \\
\hline $\mathrm{F}$ & $\begin{array}{l}\text { Görme yetersizliğinden etkilenmiş } \\
\text { Gören }\end{array}$ & $\begin{array}{l}20 \\
20\end{array}$ & $\begin{array}{l}.00 \\
.59\end{array}$ & $\begin{array}{l}17.00 \\
24.00\end{array}$ & $\begin{array}{l}340.00 \\
480.00\end{array}$ & -2.870 & .00 & 130.00 & $.004 * *$ \\
\hline $\mathrm{E}$ & $\begin{array}{l}\text { Görme yetersizliğinden etkilenmiş } \\
\text { Gören }\end{array}$ & $\begin{array}{l}20 \\
20\end{array}$ & $\begin{array}{l}1.14 \\
1.05\end{array}$ & $\begin{array}{l}16.43 \\
24.58\end{array}$ & $\begin{array}{l}328.50 \\
491.50\end{array}$ & -2.294 & 1.50 & 118.50 & $.022 *$ \\
\hline $\mathrm{D}$ & $\begin{array}{l}\text { Görme yetersizliğinden etkilenmiş } \\
\text { Gören }\end{array}$ & $\begin{array}{l}20 \\
20\end{array}$ & $\begin{array}{l}.00 \\
.22\end{array}$ & $\begin{array}{l}20.00 \\
21.00\end{array}$ & $\begin{array}{l}400.00 \\
420.00\end{array}$ & -1.000 & .00 & 190.00 & .317 \\
\hline DY & $\begin{array}{l}\text { Görme yetersizliğinden etkilenmiş } \\
\text { Gören }\end{array}$ & $\begin{array}{l}20 \\
20\end{array}$ & $\begin{array}{l}.67 \\
.48\end{array}$ & $\begin{array}{l}24.53 \\
16.48\end{array}$ & $\begin{array}{l}490.50 \\
329.50\end{array}$ & -2.432 & 1.00 & 119.50 & $.015^{*}$ \\
\hline $\mathrm{U}$ & $\begin{array}{l}\text { Görme yetersizliğinden etkilenmiş } \\
\text { Gören }\end{array}$ & $\begin{array}{l}20 \\
20\end{array}$ & $\begin{array}{l}.80 \\
.74\end{array}$ & $\begin{array}{l}19.65 \\
21.35\end{array}$ & $\begin{array}{l}393.00 \\
427.00\end{array}$ & -.659 & .00 & 183.00 & .510 \\
\hline FT & $\begin{array}{l}\text { Görme yetersizliğinden etkilenmiş } \\
\text { Gören }\end{array}$ & $\begin{array}{l}20 \\
20\end{array}$ & $\begin{array}{l}.00 \\
.60\end{array}$ & $\begin{array}{l}16.00 \\
25.00\end{array}$ & $\begin{array}{l}320.00 \\
500.00\end{array}$ & -3.354 & .00 & 110.00 & $.001 * *$ \\
\hline
\end{tabular}

Not: $\mathrm{G}=$ görmezden gelme; $\mathrm{F}$ = fiziksel yakınlık; $\mathrm{E}=$ uyumlu tepki; $\mathrm{D}=$ dikkati dağıtma; $\mathrm{DY}=$ tepki vermeden dikkati yöneltme; $\mathrm{U}=$ uyumsuz tepki; FT = fiziksel heyecan tepkisi $* p<.05 ; * * p<.01 ; * * * p<.001$.

Tablo 4 incelendiğinde görme yetersizliğinden etkilenmiş çocuklar ve gören çocukların üzgün duygu ifade tepkileriyle ilintili Görmezden Gelme $(U=89.50, z=-3.140, p<.01)$, Fiziksel Yakınlık $(U=130.00, z=$ $2.870, p<.01)$, Uyumlu Tepki $(U=118.50, z=-2.294, p<.05)$, Tepki Vermeden Dikkati Yöneltme $(U=119.50$, $z=-2.432, p<.05)$ ve Fiziksel Heyecan Tepkisi $(U=110.00, z=-3.354, p<.01)$ kategorilerinde anlaml bir farkl1lık gösterdiği görülmüştür.

Çalışmanın katılımcı grubunda yer alan farklı görme düzeylerine sahip çocukların (az gören, ağır görme yetersizliği olan ve gören çocuklar) üzgün duygu ifade tepkilerini belirlemek amaciyla Kruskal Wallis testi (Tablo 5) uygulanmıştır. 
Tablo 5

Kruskal Wallis Testi Üzgün Duygu Ifade Tepkileri Sonuçları

\begin{tabular}{|c|c|c|c|c|c|c|c|}
\hline Bağımlı değişken & Gruplar & $N$ & $S S$ & Sira ort. & $M$ & $\chi^{2}$ & $p$ \\
\hline \multirow{3}{*}{ 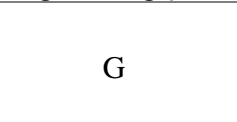 } & Az Gören & 10 & 1.56 & 20.70 & 1.00 & 14.43 & $.001 * *$ \\
\hline & Ağır & 10 & 1.08 & 31.35 & & & \\
\hline & Gören & 20 & .82 & 14.98 & & & \\
\hline \multirow{3}{*}{$\mathrm{F}$} & Az Gören & 10 & .00 & 17.00 & .00 & 8.23 & $.016 *$ \\
\hline & Ağ1r & 10 & .00 & 17.00 & & & \\
\hline & Gören & 20 & .59 & 24.00 & & & \\
\hline \multirow{3}{*}{$\mathrm{E}$} & Az Gören & 10 & 1.28 & 17.90 & 1.50 & 5.61 & .061 \\
\hline & Ağgir & 10 & 1.03 & 14.95 & & & \\
\hline & Gören & 20 & 1.05 & 24.58 & & & \\
\hline \multirow{3}{*}{$\mathrm{D}$} & Az Gören & 10 & .00 & 20.00 & .00 & 1.00 & .607 \\
\hline & Ağır & 10 & .00 & 20.00 & & & \\
\hline & Gören & 20 & .22 & 21.00 & & & \\
\hline \multirow{3}{*}{ DY } & Az Gören & 10 & .81 & 26.10 & 1.00 & 6.36 & $.041 *$ \\
\hline & Ağgir & 10 & .48 & 22.95 & & & \\
\hline & Gören & 20 & .48 & 16.48 & & & \\
\hline \multirow{3}{*}{$\mathrm{U}$} & Az Gören & 10 & 1.07 & 22.80 & .00 & 3.42 & .181 \\
\hline & Ağ1r & 10 & .00 & 16.50 & & & \\
\hline & Gören & 20 & .74 & 21.35 & & & \\
\hline \multirow{3}{*}{ FT } & Az Gören & 10 & .00 & 16.00 & .00 & 11.25 & $.004 * *$ \\
\hline & Ağglr & 10 & .00 & 16.00 & & & \\
\hline & Gören & 20 & .60 & 25.00 & & & \\
\hline
\end{tabular}

Not: $\mathrm{G}=$ görmezden gelme; $\mathrm{F}$ = fiziksel yakınlık; $\mathrm{E}=$ uyumlu tepki; $\mathrm{D}=$ dikkati dağıtma; $\mathrm{DY}=$ tepki vermeden dikkati yöneltme; $\mathrm{U}=$ uyumsuz tepki; FT = fiziksel heyecan tepkisi.

$* p<.05 ; * * p<.01 ; * * * p<.001$.

Tablo 5 incelendiğinde, az gören, ağır görme yetersizliği olan ve gören çocukların üzgün duygu ifade tepkilerinin Görmezden Gelme $(\chi 2=14.43, p<.01)$, Fiziksel Yakınlık $(\chi 2=8.23, p<.05)$, Tepki Vermeden Dikkati Yöneltme $(\chi 2=6.36, p<.05)$ ve Fiziksel Heyecan Tepkisi $\left(\chi_{2}=11.25, p<.01\right)$ kategorilerinde anlamlı bir farkl1lık gösterdiği görülmüştür. Gruplar arasında gözlemlenen anlamlı farkın hangi grubun lehine olduğunu belirlemek amacıyla post hoc testi uygulanmıştır. Tabloda yer alan gruplar arası anlamlı farklılığa bakıldığında Görmezden Gelme kategorisinde ağır görme yetersizliği olan çocuklar ile gören çocuklar arasında anlamlı bir fark olduğu; bu farklılığın ağır görme yetersizliği olan çocukların lehine olduğu belirlenmiş̧tir $(2>3, p=.000)$. Görmezden Gelme kategorisinde diğer gruplar incelendiğinden ağır görme yetersizliği olan çocuklar ile az gören çocuklar arasında anlamlı bir fark olduğu; bu farklılı̆̆ın ağır görme yetersizliği olan çocukların lehine olduğu görülmüştür $(2>1, p=.032)$. Fiziksel Yakınlık kategorisi incelendiğinde gören çocuklar ile az gören çocuklar arasında anlamlı bir fark olduğu; bu farklılığın gören çocuklar lehine olduğu anlaşılmıştır $(3>1, p=.019)$. Fiziksel Yakınlık kategorisinde diğer gruplar arasındaki ilişkiye bakıldığında gören çocuklar ile ağır görme yetersizliği olan çocuklar arasında anlamlı bir fark olduğu; bu farklılığın gören çocuklar lehine olduğu anlaşılmıştır $(3>2, p$ $=.019$ ). Tepki Vermeden Dikkati Yöneltme kategorisinde ise az gören çocuklar ile gören çocuklar arasında anlamlı bir fark olduğu; bu farklılığın az gören çocuklar lehine olduğu belirlenmiştir $(1>3, p=.018)$. Fiziksel Heyecan Tepkisi kategorisi incelendiğinde gören çocuklar ile az gören çocuklar arasında anlamlı bir fark olduğu; bu farklılığın gören çocuklar lehine olduğu anlaşılmıştır (3 > 1, $p=.006)$. Fiziksel Heyecan Tepkisi kategorisinde gören çocuklar ile ağır görme yetersizliği olan çocuklar arasında anlamlı bir fark olduğu; bu farklılığın gören çocuklar lehine olduğu belirlenmiştir $(3>2, p=.006)$.

\section{Tartışma}

Araştırmada az gören, ağır görme yetersizliğinden etkilenmiş ve gören çocukların duygu ifadeleri tepkileri karşılaştırılmıştır. Bu doğrultuda, çocukların akranıyla birlikte bir oyunu tamamladıklarında akranının kendi sırası gelip pekiştireç alarak mutlu olduğu durumda ve akranının sırası gelip oyuncağı elde edemediği için üzgün olduğu duygu ifadeleri karşısında sergiledikleri duygu tepkileri karşılaştırılarak incelenmiştir.

Araştırmanın bulguları incelendiğinde görme yetersizliği olan ve gören çocukların mutlu duygu ifade tepkilerinde Görmezden Gelme, Fiziksel Yakınlık, Uyumlu Tepki ve Fiziksel Heyecan Tepkisi kategorilerinde 
anlamlı olarak farklılaştığı görülmüştür. Katılımcı çocukların duygu tepkileri ile görme düzeylerinin ilişkisini daha ayrıntılı olarak belirleyebilmek amacıyla az gören, ağır görme yetersizliğinden etkilenmiş ve gören çocukların mutlu duygu ifadeleri tepkileri incelendiğinde, Görmezden Gelme, Fiziksel Yakınlık ve Uyumlu Tepki kategorilerinde çocukların tepkilerinin gruplar arasında farklılaştığı belirlenmiştir. Araştırmanın bulguları az gören çocuklar ile ağır görme yetersizliği olan çocukların gören akranlarına oranla Görmezden Gelme kategorisinde daha fazla puan aldıklarını göstermiştir. Diğer taraftan Fiziksel Yakınlık ve Uyumlu Tepki kategorilerinde gören çocukların az gören ve ağır görme yetersizliği olan çocuklara oranla daha fazla puan aldıkları saptanmıştır.

Araştırmadan elde edilen bulgular görme yetersizliğinden etkilenmiş çocukların mutlu duygu ifade tepkilerinde gören akranlarına oranla daha fazla görmezden gelme tepkileri sergilediklerini göstermiştir. Alanyazında görme yetersizliğinden etkilenmiş çocukların diğer bireylerin yüz ifadelerini ve beden dilini okuma becerilerinde sınırlılıkları olduğu ve söz konusu sınırlılığın çocukların iletişim becerilerinin de dolaylı olarak etkilenmesine neden olduğu ifade edilmektedir (Wolffe, 2000). Bu araştırmada görme yetersizliği olan çocukların daha fazla görmezden gelme tepkilerini sergilemeleri bulgusu, akranı tarafından sergilenen duygulara yönelik tepkisiz kaldıkları ve sınırlı düzeyde ilgilerini paylaştıklarını gösterir niteliktedir. Araştırmada kodlama sırasında ağır görme yetersizliğinden etkilenmiş bazı katılımcı çocukların Görmezden Gelme kategorisi içerisinde yer alan akranıyla konuşmadan sessiz bir şekilde oturma davranışını sıklıkla sergiledikleri belirlenmiştir. Örneğin; araştırmacı gözlemlerine dayanarak çalışma sırasında ağır görme yetersizliğinden etkilenmiş bir katılımcı çocuk çiftinin beraber oyunu tamamlamalarının ardından akranı ödülünü aldıktan sonra katılımcı çocuğun konuşmadan oturduğu görülmüştür. Tüm girdiler içerisinde en çok görme girdisinin sosyal etkileşim değişimlerinde, başka kişilerin yüz ifadelerini gözlemleme olanağ sağladığı ancak görme yetersizliğinden etkilenmiş çocuklar için bu durumun bir sınırlılık oluşturabileceği ifade edilmektedir (Lieber \& Umansky, 2004). Örneğin; Lang ve diğerleri (2017) tarafından gerçekleştirilen bir çalışmada 12-36 ay aralığında görme yetersizliğinden etkilenmiş bebeklerin görme düzeyleri azaldıkça başkalarıyla ilgiyi paylaşma, çevreyi araştırma, akran ya da yetişkinle iletişimi başlatma, akranı ile taklit, oyun becerilerinde daha fazla problem yaşadıkları gösterilmişstir. Benzer şekilde, Alimovic de (2013) bir çalışmasında görme yetersizliğinden etkilenmiş çocukların gören çocuklara göre daha fazla duygusal problem yaşadıklarını ve sosyal becerilerde sınırlılıklar sergilediklerini rapor etmiştir. Alanyazında bu bulgular doğrultusunda görme yetersizliğinden etkilenmiş çocukların duygu ifade tepkilerinin değerlendirilmesinin önemi anlaşılmaktadır. Sosyal etkileşimler genel olarak yüz ifadeleri gibi insanlar tarafından güç algılanan ipuçlarına önemli ölçüde dayandırılmaktadır (Hallahan \& Kauffman, 2006). Sosyal bağlam farklılıkları ve duyguların karmaşıklığı ise duyguları anlama ve uygun tepki vermeyi etkileyebilmektedir (Töret vd., 2019). Diğer taraftan Fiziksel Yakınlık ve Uyumlu Tepki kategorilerini gören çocukların daha fazla sergilemeleri bu çocukların akranının verdiği tepkiyle aynı duyguları paylaştıklarını ve duygularını ifade ederken fiziksel temas kurduklarını göstermiştir. Kodlama sürecinde gören bazı katılımcı çocukların oyunu tamamlayıp akranı ödülü aldıktan sonra Fiziksel Yakınlık kategorisi içerisinde yer alan birbirlerine sarılma, kucaklama davranışını sıklıkla yaptıkları gözlenmiştir. Örneğin; gören bazı katılımcı çocuk çiftlerinde oyunu tamamlayıp akranı ödülü aldıktan sonra katılımcı çocuğun akranının yanına gittiği, birbirlerine sarıldıkları, birbirlerini kucakladıkları gözlenmiştir.

Araştırmanın görme yetersizliği olan ve gören çocukların üzgün duygu ifadelerine yönelik tepkileri karşılaştırıldığında grupların Görmezden Gelme, Fiziksel Yakınlık, Uyumlu Tepki, Tepki Vermeden Dikkatini Yöneltme ve Fiziksel Heyecan Tepkisi kategorilerinde farklılaştığı gözlenmiştir. Çocukların görme düzeylerinin üzgün duygu ifade tepkileri ile ilişkisinin derinlemesine incelenmesine yönelik olarak, az gören, ağır görme yetersizliğinden etkilenmiş ve gören çocukların tepkileri karşılaştırıldığında grupların Görmezden Gelme, Fiziksel Yakınlık, Tepki Vermeden Dikkatini Yöneltme ve Fiziksel Heyecan Tepkisi kategorilerinde farklılaştığı gözlenmiştir. Üzgün duygu ifade tepkileriyle ilintili ağır görme yetersizliğinden etkilenmiş çocukların az gören ve gören akranlarına oranla Görmezden Gelme kategorisinde daha fazla puan aldıkları belirlenmiştir. Gören çocukların ise az gören ve ağır görme yetersizliği olan akranlarına oranla Fiziksel Yakınlık ve Fiziksel Heyecan Tepkisi kategorilerinde daha fazla puan aldıkları saptanmıştır. Az gören çocukların ise gören akranlarına oranla Tepki Vermeden Dikkatini Yöneltme kategorisinde daha fazla puan aldıkları gözlenmiştir.

Araştırmanın bulguları görme yetersizliğinden etkilenmiş çocukların (ağır görme yetersizliğinden etkilenmiş ve az gören) üzgün duygu ifade tepkilerine ilişkin gören akranlarına oranla Görmezden Gelme ve Tepki Vermeden Dikkatini Yöneltme davranışlarını daha yoğun sergilediklerini göstermiştir. Örneğin; görme yetersizliğinden etkilenmiş bazı katılımcı çocuk çiftlerinde akranı oyuncağı elde edemediğinde çevresindeki olayı dinlemeye çalıştı̆̆ı, dikkat kesildiği fakat herhangi bir tepki vermeden birkaç saniyelik duraksamadan sonra hiçbir şey olmamış gibi oyunlarına devam ettikleri gözlenmiştir. Araştırmanın sonuçları incelendiğinde özellikle ağır 
görme yetersizliğinden etkilenmiş çocukların az gören çocuklara göre daha fazla Görmezden Gelme davranışlarını sergiledikleri görülmüştür. Bu bulgu duygu ifade tepkilerinde görme düzeyinin önemini gösterir niteliktedir. Araştırmada az gören çocukların ise akranının sergilediği duygulara yönelik tepkisiz kalma, ilgisini yöneltmeme veya durum karşısında tepki vermeden çevresindeki olayları dinlemeye çalıştıkları gözlenmiştir. Araştırmanın söz konusu bulguları, alanyazında görme yetersizliğinden etkilenmiş çocukların daha fazla kendi başlarına oyun oynadıklarını ifade eden çalışma bulguları ile benzerlik göstermektedir (Crocker \& Orr, 1996). Bununla birlikte alanyazında görme yetersizliğinden etkilenmiş çocukların sosyal becerilerinde sınırlılık sergiledikleri (Smith, 2001) ve yaşadıkları bu sınırlılıktan dolayı genellikle gören akranları tarafından kabul görmedikleri (Culatta \& Tompkins, 1999) vurgulanmaktadır. Nitekim daha büyük yaş grupları ile gerçekleştirilen bir çalışmada görme yetersizliğinden etkilenmiş öğrencilerin gören öğrencilere göre daha fazla duygu ve akran ilişkileri problemleri yaşadıkları bununla birlikte duygu problemlerinin de yaşla birlikte azalma yerine artış gösterdiği rapor edilmiştir (Pinquart \& Pfeiffer, 2012). Diğer taraftan, gören çocukların akranına yönelik olarak Fiziksel Yakınlık ve Fiziksel Heyecan Tepkisi kategorilerini daha yüksek oranda sergilemeleri bu grubun fiziksel temas ve akranının içinde bulunduğu üzgün duruma yönelik fiziksel hareketlerle de duygusunu dışarı yansıttığı gözlenmiştir. Araştırmada gören bazı katılımcı çocukların akranı oyuncağı elde edemediğinde Fiziksel Yakınlık kategorisi içerisinde yer alan akranının yüzüne doğru bakışlarını çevirme, yanına gitme ve sarılma davranışlarını yoğun bir şekilde sergiledikleri gözlenmiştir. Örneğin; gören bazı katılımcı çocuk çiftlerinde akranı oyuncağı elde edemediğinde akranının yüzüne doğru bakışlarını çevirdiği, yanına doğru gittiği, duygusunu değiştirmeye çalışır gibi sarıldığı gözlenmiştir.

$\mathrm{Bu}$ araştırmada katılımcı çocukların farklı duygu ifadelerine olan tepkileri incelendiğinde ağır görme yetersizliğinden etkilenmiş çocukların az gören çocuklara oranla akranının sergilediği duygu ifadelerini daha fazla görmezden geldikleri ve tepkisiz kaldıkları görülmüştür. Bu bulgular görme yetersizliğinden etkilenmiş çocukların görme düzeylerine göre duygu ifadeleri tepkilerinin etkilenebileceğini göstermektedir. Genel olarak araştırmanın bulguları 1şığında her iki duygu durumunda da görme yetersizliğinden etkilenmiş çocukların gören akranlarına oranla daha yoğun bir şekilde Görmezden Gelme davranışlarını sergiledikleri dikkat çekmektedir. Bu bulgu alanyazında görme girdilerindeki sınırlılıklardan ötürü görme yetersizliği olan çocukların duyguları anlamalarında farklılıklar olduğunu gösteren araştırmaları destekler nitelikte görülebilir (Alimovic, 2013; Lang vd., 2017). Bir diğer bakış açısından ise okul öncesi dönemde görme becerileri yoksunluğu görme yetersizliğinden etkilenmiş çocukların duygu durumlarında verdikleri tepkilerinin önemini gözlemleyememe ve uygun duygu tepki üretmeyi öğrenmede sinırlılıklar sergileme sonucunu ortaya çıkarıyor olabilir. Bu durum ise görme yetersizliği olan çocukların sosyal etkileşim ve ilişkileri sürdürmelerinde, akranları ile karşılıklı etkileşim sınırlılıkları doğurabilir. Nitekim alanyazında çocukların sergiledikleri duygusal becerileri üzerinde aileleri ve akranları ile paylaştıkları duygu içerikli iletişimler ve yaşantıların etkileri özellikle vurgulanmaktadır (Joireman vd., 2002; Saarni, 2008). Özetle, bu araştırmadan elde edilen bilgiler ışı̆̆ında, görme yetersizliğinden etkilenmiş çocukların okul öncesi dönem programlarına duygusal tepkilerin paylaşıldığı ve sosyal durumlara uygun sosyal tepki üretme davranı̧̧larının öğretiminin eklenmesi görme yetersizliği olan çocukların olumlu duygusal ve sosyal deneyimlerden mahrum kalmalarını önleme potansiyelindedir (Özdemir, 2013).

Son olarak, bu araştırmada az gören, ağır görme yetersizliğinden etkilenmiş ve gören çocukların duygu ifadeleri tepkileri karşılaştırılmıştır. Çalışmanın katılımcı grubunu oluşturan herhangi bir ek yetersizlik veya gelişimsel gecikme sergilemeyen görme yetersizliğinden etkilenmiş çocuklara (az gören ve ağır görme yetersizliğinden etkilenmiş) erişimin sınırlı olmasından ötürü katılımcı sayısının azlığı bu çalışmanın katılımcı sayısı sınırlılığını oluşturmaktadır. Diğer taraftan, bu çalışmada mutlu ve üzgün olmak üzere iki duygu durumuna yönelik katılımcı çocukların tepkilerinin incelenmesine yer verilmiştir. İleri araştırmalarda çocukların temel duygulardan meraklı, şaşkın, korkmuş, kızgın, iğrenmiş gibi diğer duygu ifadelerini akranlarının yaşadıkları durumlardaki duygu tepkileri incelenebilir. Gerçek durum uygulamalarına dayalı bu araştırmanın farklı duygu durumlarını da içermesi pek çok deneysel koşulun kontrolü bağlamında uzun süreli uygulama ve veri toplama süreçlerini gerektirmektedir. Söz konusu duygu çeşitliliği daha geniş bir kapsayıcılıkla görme yetersizliği olan çocukların duygu tepkilerinin incelenmesini sağlayacaktır. Bu çalışmada 4-6 yaş aralığındaki okul öncesi dönem çocukları ile çalışılmıştır. İleri araştırmalarda orta çocukluk dönemi, ergenlik dönemi ve yetişkinlik dönemindeki görme yetersizliğinden etkilenmiş bireylerin duygu ifadelerine olan tepkileri de incelenebilir. Ayrıca boyamsal olarak da bu çocukların farklı duygu ifadeleri tepkileri değerlendirilebilir. Böyle bir inceleme ise görme yetersizliğinden etkilenmiş bireylerde ilerleyen yaşlarda uygun sosyal tepki üretimlerinin gelişimsel sürecini değerlendirmeye imkân sağlayacaktır. Her ne kadar alanyazında var olan bulgular, görme yetersizliği olan bireylerde duygu problemlerinin yaşla beraber artış gösterdiğini rapor etse de (Pinquart \& Pfeiffer, 2012), söz konusu bulgulardan görme yetersizliği olan bireylerin ilerleyen yaşlarda duygu durumlarına verdikleri tepkilerde bir değişim veya ilerlemenin olup olmadığını yorumlamak mümkün değildir. 
Daha ilerleyen boyutta ise belki de bu araştırmadan elde edilen bulgularda olduğu gibi, gören çocuklarla akran reddini oluşturan süreçte sadece gören çocuk tercihleri değil ancak görme yetersizliğinden etkilenmiş çocuk tepkilerinin de söz konusu sosyal oluşumlara dinamik olarak katkı sağlayıp sağlamadığı incelenebilir. Tüm bireyler günlük sosyal etkileşimlerinde empatik paylaşımlar içerisinde olabilecekleri kişilerle etkileşimde kalmayı daha fazla tercih ederler (Eisenberg \& Fabes, 1990). İnsan ilişkilerinde empati bireyin derinlemesine bir şekilde anlaşılma ihtiyacına cevap verir (Schmid, 2001) ve duygusal açıdan anlaşılmak insana kendini iyi hissettireceği gibi bu beceriyi geliştiren insanların da çevrelerince daha fazla kabul görmesini sağladığı kabul edilir (Özer, 2016).

\section{Yazarların Katkı Düzeyleri}

Çalışma konusunu belirleme, araştırma deseni: Prof. Dr. Selda Özdemir; veri toplama, verilerin analizi ve çalışmanın raporlanması: Arş. Gör. Hale Çotuk. 


\section{Kaynaklar}

Ahn, H. J. (2003). Teachers' role in the socialization of emotion in three child care centers (Doctoral dissertation, Pennsylvania State University). ProQuest Dissertations and Theses database. (UMI No. 3096920).

Ahn, H. J. (2005). Child care teachers' strategies in children's socialization of emotion. Early Child Development and Care, 175(1), 49-61. https://www.tandfonline.com/doi/full/10.1080/0300443042000230320

Alimovic, S. (2013). Emotional and behavioural problems in children with visual impairment, intellectual and multiple disabilities. Journal of Intellectual Disability Research, 57(2), 153-160. https://doi.org/10.1111/j.1365-2788.2012.01562.x

Aslan, C., Özdemir, S., Demiryürek, P., \& Çotuk, H. (2015). Görme yetersizliğinden etkilenen ve normal gelişim gösteren çocukların oyun çeşitlilik ve karmaşıklık düzeylerinin incelenmesi. International Journal of $\begin{array}{lllll}\text { Early Childhood } & \text { Special }\end{array}$ https://d1wqtxts1xzle7.cloudfront.net/40973171/oyun_makale.pdf?1452023169=\&response-contentdisposition=inline\%3B+filename\%3DGorme Yetersizliginden_Etkilenen_ve_Norm.pdf\&Expires $=160$ $\underline{8677509}$

Berk, L. E. (2002). Infants and children: Prenatal through middle childhood (4th ed.). Allyn \& Bacon.

Büyüköztürk, Ş., Kılıç Çakmak, E., Akgün, Ö. E., Karadeniz, Ş., \& Demirel, F. (2014). Bilimsel araştırma yöntemleri [Scientific research methods] (15. bask1). Pegem.

Cole, M., \& Cole, S. R. (2001). The development of children (4th ed.). Worth Publishers.

Crocker, A. D., \& Orr, R. R. (1996). Social behaviors of children with visual impairments enrolled in preschool programs. Exceptional Children, 62(5), 451-462. https://journals.sagepub.com/doi/abs/10.1177/001440299606200505

Culatta, R. A., \& Tompkins, J. R. (1999). Fundamentals of special education. What every teacher needs to know. Prentice Hall.

Demir, F. E., \& Ozdemir, S. (2016a). A comparison of social skills of students with visual impairments and typically developing students. IJAEDU-International E-Journal of Advances in Education, 2(4), 85-94. https://www.researchgate.net/profile/Fatih_Demir20/publication/301577994

Demir, F. E., \& Ozdemir, S. (2016b). A comparison of problem behaviors of students with visual impairments and typically developing students. IJAEDU-International E-Journal of Advances in Education, 2(4), 122-131. https://www.researchgate.net/profile/Fatih_Demir20/publication/301577995

DeMorat, M. G. (1998). Emotion socialization in the classroom context: A functionalist analysis (Publication No. 9921584) [Doctoral dissertation, University of California-Santa Barbara]. ProQuest Dissertations and Theses Global.

Denham, S. A., Bassett, H. H., \& Wyatt, T. (2007). The socialization of emotional competence. In J. E. Grusec \& P. D. Hastings (Eds.), Handbook of socialization: Theory and research (pp. 614-637). Guilford Press.

DiGennaro, F. D., Martens, B. K., \& Kleinmann, A. E. (2007). A comparison of performance feedback procedures on teachers' treatment implementation integrity and students' inappropriate behavior in special education classrooms. Journal of Applied Behavior Analysis, 40(3), 447-461. https://onlinelibrary.wiley.com/doi/abs/10.1901/jaba.2007.40-447

Dünya Sağlı Örgütü [World Health Organization] (2018). Blindness and vision impairment. https://www.who.int/news-room/fact-sheets/detail/blindness-and-visual-impairment

Eisenberg, N., \& Fabes, R. A. (1990). Empathy: Conceptualization, measurement, and relation to prosocial behavior. Motivation and Emotion, 14(2), 131-149. https://link.springer.com/article/10.1007/BF00991640

Ekman, P., \& Friesen, W. V. (2003). Unmasking the face: A guide to recognizing emotions from facial expressions. Malor Books. 
Field, T. M., Woodson, R., Greenberg, R., \& Cohen, D. (1982). Discrimination and imitation of facial expression by neonates. Science, 218(4568), 179-181. https://science.sciencemag.org/content/218/4568/179.abstract

Franzese, M., \& Iuliano, A. (2019). Correlation analysis. In S. Ranganathan, M. Gribskov, K. Nakai, \& C. Schönbach (Eds.), Encyclopedia of bioinformatics and computational biology: ABC of bioinformatics (pp. 706-721). Elsevier.

Galati, D., Miceli, R., \& Sini, B. (2001). Judging and coding facial expression of emotions in congenitally blind children. International Journal of Behavioral Development, 25(3), 268-278. https://www.tandfonline.com/doi/abs/10.1080/01650250042000393

Galati, D., Sini, B., Schmidt, S., \& Tinti, C. (2003). Spontaneous facial expressions in congenitally blind and sighted children aged 8-11. Journal of Visual Impairment \& Blindness, 97(7), 418-428. https://journals.sagepub.com/doi/abs/10.1177/0145482X0309700704

Garner, P. W., Robertson, S., \& Smith, G. (1997). Preschool children's emotional expressions with peers: The roles of gender and emotion socialization. Sex Roles, 36(11-12), 675-691. https://link.springer.com/article/10.1023/A:1025601104859

Hall, E., Lamb, M., \& Perlmutter, M. (1986). Child psychology today (2nd ed.). Random House.

Hallahan, D. P., \& Kauffman, J. M. (2006). Exceptional learners: An introduction to special education (10th ed.). Allyn \& Bacon.

Heyman, R. E., Lorber, M. F., Eddy, J. M., \& West, T. V. (2014). Behavioral observation and coding. In H. T. Reis \& C. M. Judd (Eds.), Handbook of research methods in social and personality psychology (2nd ed.). Cambridge University Press.

Howard, V. F., Williams, B. F., \& Lepper, C. (2005). Very young children with special needs: A formative approach for today's children (3rd ed.). Pearson Prentice Hall.

Hyson, M. (2004). The emotional development of young children: Building an emotion-centered curriculum (2nd ed.). Teachers College Press.

İrtiş, A., \& Özdemir, S. (2019). A comparison of mother-child interactions in children with visual impairments and typically developing children. Education and Science, 44(200), 409-428. https://www.researchgate.net/publication/336901485

Johnson, W. F., Emde, R. N., Pannabecker, B. J., Stenberg, C. R., \& Davis, M. H. (1982). Maternal perception of infant emotion from birth through 18 months. Infant Behavior and Development, 5(2-4), 313-322. https://www.sciencedirect.com/science/article/abs/pii/S0163638382800416

Joireman, J. A., Needham, T. L., \& Cummings, A. L. (2002). Relationships between dimensions of attachment and empathy. North American Journal of Psychology, 3(3), 63-80. https://www.researchgate.net/profile/Jeff_Joireman/publication/232451701_

Junn, E. N., \& Boyatzis, C. J. (2009). Annual editions: Child growth and development (6th ed.). McGrawHill/Dushkin.

Kazdin, A. E. (1982). Single-case research designs: Methods for clinical and applied settings. Oxford University Press.

Keltner, D., \& Haidt, J. (1999). Social functions of emotions at four levels of analysis. Cognition \& Emotion, 13(5), 505-521. https://www.tandfonline.com/doi/abs/10.1080/026999399379168

Lang, M., Hintermair, M., \& Sarimski, K. (2017). Social-emotional competences in very young visually impaired children. British Journal of Visual Impairment, 35(1), 29-43. https://journals.sagepub.com/doi/full/10.1177/0264619616677171

Lewis, M. (2008). Self-conscious emotions: Embarrassment, pride, shame and guilt. In M. Lewis, J. M. HavilandJones, \& L. F. Barrett (Eds.). Handbook of emotions (pp. 742-756). The Guilford Press.

Lewis, V. (1993). Development and handicap. Blackwell. 
Lieber, J., \& Umansky, W. (2004). Social and emotional development. In S. R. Hooper \& W. Umansky (Eds.). Young children with special needs (pp. 410-446). Pearson Prentice Hall.

McLoyd, V. C. (1983). The effects of the structure of play objects on the pretend play of low-income preschool children. Child Development, 54(3), 626-635. https://www.jstor.org/stable/1130049

Meltzoff, A. N., \& Moore, M. K. (1977). Imitation of facial and manual gestures by human neonates. Science, 198(4312), 75-78. https://science.sciencemag.org/content/198/4312/75.abstract

Meltzoff, A. N., \& Moore, M. K. (1983). Newborn infants imitate adult facial gestures. Child Development, 54(3), 702-709. https://www.jstor.org/stable/1130058

Özdemir, S. (2013). Sosyal becerilerin ve sosyal uyumun desteklenmesi. İ. H. Diken (Ed.), Illköğretimde kaynaştırma içinde (ss. 291-324). Pegem Akademi.

Özer, G. (2016). Empati eğitim programının anaokulu çocuklarının empatik ve prososyal becerilerine etkisinin incelenmesi [Analysis of the impact of empathy education program on the prosocial and empathetic skills of preschool children] (Tez Numaras1: 435220) [Doktora tezi, Hacettepe Üniversitesi]. Yükseköğretim Kurulu Ulusal Tez Merkezi.

Özkubat, U., \& Özdemir, S. (2012). Görme yetersizliğinden etkilenmiş ve normal gelişim gösteren çocukların sosyal becerilerinin karşılaştırılması [A comparison of social skills in Turkish children with visual impairments and typically developing children]. Ankara Üniversitesi Eğitim Bilimleri Fakültesi Özel Eğitim Dergisi, $13(1), \quad 1-14$. https://dspace.ankara.edu.tr/xmlui/bitstream/handle/20.500.12575/47306/18615

Papalia, D. E., Olds, S. W., \& Feldman, R. D. (2006). A child's world: Infancy through adolescence (10th ed.) (pp.198-235). Mc Graw Hill.

Peleg, G., Katzir, G., Peleg, O., Kamara, M., Brodsky, L., Hel-Or, H., Keren, D., \& Nevo, E. (2009). Facial expressions in various emotional states in congenitally blind and sighted subjects. Israel Journal of Ecology \& Evolution, 55(1), 11-30. https://www.tandfonline.com/doi/abs/10.1560/IJEE.55.1.11

Pinquart, M., \& Pfeiffer, J. P. (2012). Psychological adjustment in adolescents with vision impairment. International Journal of Disability Development and Education, 59(2), 145-155. https://www.tandfonline.com/doi/full/10.1080/1034912X.2012.676416

Reeve, J. (2005). Understanding motivation and emotion (4th ed.). John Wiley \& Sons.

Saarni, C. (2008). The interface of emotional development with social context. In M. Lewis, J. M. Haviland-Jones, \& L. F. Barrett (Eds.), Handbook of emotions (pp. 332-347). The Guilford Press.

Santrock, J. W. (2004). Child development (10th ed.). McGraw-Hill.

Savaşır, I., Sezgin, N., \& Erol, N. (1994). Ankara Gelişim Tarama Envanteri el kitabı [Ankara Development Screening Inventory manual]. Ankara Üniversitesi Tıp Fakültesi.

Schmid, P. F. (2001). Comprehension: The art of not knowing. Dialogical and ethical perspectives on empathy as dialogue in personal and person-centred relationships. In S. Haugh \& T. Merry (Eds.), Rogers' therapeutic conditions: Evolution, theory and practice. Empathy (pp. 53-71). PCCS Books.

Smith, D. D. (2001). Introduction to special education: Teaching in an age of opportunity (4th ed.). Allyn \& Bacon.

Snow, C. W., \& McGaha, C. G. (2003). Infant development (3rd ed.). Prentice Hall.

Snowden, R., Thompson, P., \& Troscianko, T. (2006). Basic vision: An introduction to visual perception. Oxford University Press.

Stanton-Chapman, T. L., \& Raver, S. A. (2009). Promoting social and emotional development. In S. A. Raver (Ed.). Early childhood special education 0 to 8 years: Strategies for positive outcomes (pp. 199-222). Merrill Pearson. 
Töret, Z., Özdemir, S., \& Akın-Bülbül, I. (2019). Ebeveynlerin otizm spektrum bozukluğu olan çocuklarının duygu temelli tepkilerine yönelik görüşleri [Perceptions of parents about emotion based responses of their children with autism spectrum disorders] Buca Eğitim Fakültesi Dergisi, 47, 14-35. https://www.researchgate.net/publication/334549777

Tröster, H., \& Brambring, M. (1992). Early social-emotional development in blind infants. Child: Care, Health and Development, 18(4), 207-227. https://onlinelibrary.wiley.com/doi/abs/10.1111/j.13652214.1992.tb00355.x

Wall, K. (2006). Special needs and early years (2nd ed.). Paul Chapman Publishing.

Wittmer, D. S., \& Petersen, S. H. (2006). Infant and toddler development and responsive program planning: A relationship-based approach. Pearson Prentice Hall.

Wolffe, K. E. (2000). Adults with low vision: Personal, social and independent living needs. In A. L. Corn \& A. J. Koenig (Eds.). Foundations of low vision: Clinical and functional perspectives (pp. 322-339). AFB Press.

Young-Browne, G., Rosenfeld, H. M., \& Horowitz, F. D. (1977). Infant discrimination of facial expressions. Child Development, 48(2), 555-562. https://www.jstor.org/stable/1128653 


\section{Ankara University Faculty of Educational Sciences Journal of Special Education}

2021, 22(3), 543-567
RESEARCH

Recieved Date: 03.01.20

Accepted Date: 29.10.20

OnlineFirst: 21.01 .21

\title{
A Comparison of the Reactions to Emotional Expressions of Children with Visual Impairments and Sighted Children
}

\author{
Hale Çotuk 1
}

\author{
Selda Özdemir iD 2
}

\begin{abstract}
Introduction: Facial expressions provide emotional exchange among people. In this study, children's reactions to happy and sad emotional expressions were examined during play time.

Method: The total study sample was 20 children with visual impairments $(10$ children with severe visual impairments, 10 children with low vision) and 20 sighted children who were between the age of 4 and 6 years. Happy and sad emotional states were reflected by peer partners during play interactions. Children with visual impairments and sighted children's reactions to peer's emotional states were observed. Coding scheme included seven categories; ignorance, physical comforting, positive response, distraction, directing attention without reacting, negative response, and physical excitement response.
\end{abstract}

Findings: Findings of the study showed that there was a difference between the emotional expression reactions of children with visual impairments and sighted children. Results indicated that children with visual impairments displayed more ignorance behaviors than sighted children.

Discussion: Children's reactions to happy and sad emotional expressions were examined in this study. The findings of the study were discussed and suggestions for future studies were provided

Keywords: Children with visual impairments, children with low vision, emotions, reactions to emotional expressions, happy, sad.

To cite: Çotuk, H., \& Özdemir, S. (2021). A comparison of the reactions to emotional expressions of children with visual impairments and sighted children. Ankara University Faculty of Educational Sciences Journal of Special Education, 22(3), 543-567. https://doi.org/10.21565/ozelegitimdergisi.669915

${ }^{1}$ Corresponding Author: Res. Assist., Gazi University, E-mail: halecotuk@ gmail.com, https://orcid.org/0000-0003-4639-9216 ${ }^{2}$ Prof., Dr., Hacettepe University, E-mail: seldaozdemir@ hacettepe.edu.tr, https://orcid.org/0000-0001-9205-5946 


\section{Introduction}

Facial expressions are universal and provide exchange of emotions among people (Snowden et al., 2006). Emotional expressions depicting happiness, curiosity, confusion, fear, anger, sadness and disgust are defined as basic emotions (Berk, 2002). They are classified by researchers in different ways, but the most common feature of all classifications is that emotions are divided into two major categories: Positive emotions and negative emotions (Santrock, 2004). Emotional expressions are the basic form of communication for children (Wittmer \& Petersen, 2006). Some researchers have shown that babies can distinguish and copy human facial expressions during early childhood period (Field et al., 1982; Meltzoff \& Moore, 1977, 1983). It has been well known that people engage in social interactions using various interactional clues including facial expressions which are perceived as subtle by most people (Hallahan \& Kauffman, 2006). Some of the researchers assert that emotional expressions affect social relationships. Many researchers also suggest that there is a strong link between emotional and social development (Hall et al., 1986; Howard et al., 2005).

Due to the lack of visual input, children with visual impairments tend to display significant limitations in the area of recognizing facial expressions (Wolffe, 2000). Some researchers argue that this negatively affects children's understanding of various emotions and in turn their social development (Alimovic, 2013; Lang et al., 2017). Lang et al. (2017) examined social emotional development of children with visual impairments (12-36 months). Their results showed that babies displayed lesser interest in interacting with other people, searching their environment, initiating communication with peers or adults, and imitating peers in general, and imitating play behaviors of other children as their vision levels decreased. In another study, researchers demonstrated that children with visual impairments between the ages of 4 and 11 had more emotional and social problems than sighted children (Alimovic, 2013). On the other hand, some of the researchers reported that the components of facial expressions were innate (Galati at al, 2001; Galati at al., 2003; Peleg et al., 2009). Accordingly, there are some studies showing that facial expressions of children with visual impairments are similar to their sighted peers (Galati et al., 2001; Galati et al., 2003).

Wolffe (2000) reported that children with visual impairments have difficulties in recognizing facial expressions due to their lack of visual input and experience problems with understanding people's emotions (Alimovic, 2013; Lang et al., 2017; Lieber \& Umansky, 2017). Thus, it is important to detect whether delays in reactions to emotional expressions and differences can be found in children with visual impairments in early years or not. In addition, identifying to what extent visual perception may have a correlation with children's reactions to emotional expressions is critical. Thus, the purpose of this study was to compare emotional reactions of children with severe visual impairments, children with low vision and sighted children to other's emotional expressions during play.

\section{Method}

The study was implemented with 10 children with severe visual impairments, 10 children with low vision, and 20 sighted children who were between 4 and 6 years of age. The study sample consisted of children who attended regular primary and elementary schools (kindergarten classrooms) and segregated special education schools for children with visual impairments. The criteria for children with visual impairments (both for children with severe visual impairments and children with low vision) were; (a) being between 48 and 72 months of age, (b) having a clinical diagnosis of visual impairments without having an additional disability, and (c) having ageappropriate language and cognitive skills assessed through the use of the Ankara Development Screening Inventory (ADSI) (Savaşır et al., 1994). The criteria for sighted children were as followed: (a) being between 48 and 72 months of age, (b) having no developmental disability or developmental risks as reported by children's teachers and parents, and (c) having age-appropriate language and cognitive skills assessed via the use of ADSI (Savaşır et al., 1994). Parental informed consents were received to ensure ethical research practices (see Table 1). Children's willingness to participate in the study was also considered. This study was conducted during free play sessions within the schools where children attended. 
Table 1

Children with Low Vision, Children with Severe Visual Impairments and Sighted Children's Demographic Information

\begin{tabular}{lccccc}
\hline \multicolumn{1}{c}{ Participants } & \multicolumn{2}{c}{ Age (month) } & \multicolumn{2}{c}{ Sex } \\
\hline Low vision & $\bar{X}$ & $S D$ & $X_{\min }-X_{\max }$ & Female & Male \\
Severe visual impairment & 65.10 & 2.54 & $52-76$ & 5 & 5 \\
Sighted & 66.70 & 2.43 & $55-77$ & 1 & 9 \\
\hline
\end{tabular}

\section{Procedure}

Children's reactions to emotional expressions were observed in the contexts of happy and sad feelings, which were two basic emotions and also represented positive and negative emotions. Initially, children's reactions to happy expressions were examined. Each child was matched with a peer. The first author presented a tactile puzzle to the children as a play medium. She explained that when children put the pieces of the puzzle in its order and completed it successfully, they would be allowed to play with a special toy. The researcher also explained that children would be allowed to play with the toy by taking turns. At the end of the play, the prize was given first to the peer to make the peer happy and to observe the target child's reactions. The researcher recorded the entire sessions to further code and analyze the children's emotional reactions to peer's emotions.

The same procedure was implemented in the sad emotion condition. Children's reactions to peer's sad emotional expressions were examined. The researcher stated that there was a new and exciting toy and children could play with that toy after finishing their play. She gave the toy (a teapot with exciting lights and sounds) to children. Children were allowed to play with the toy by taking turns. At the end of the play, the researcher led the child to play with the toy, however when it was peer's turn to play, the researcher told the peer that the time was up. As the other child missed the chance of playing with the new toy, her/his emotional expressions and target child's emotional reactions were recorded.

\section{Coding Observation Data}

The children's emotional expressions were coded from the video recording using seven different categories. The categories were adapted from the studies of Ahn (2003) and Demorat (1998). Coding categories included: Ignorance (I), Physical Comforting (C), Positive Response (PR), Distraction (D), Directing Attention without Reacting (DA), Negative Response (NR), Physical Excitement Response (PE). The coding categories were: (a) Ignorance: Children ignore peer's emotion, display no interest and continue their own play activity as if nothing happened. (b) Physical Comforting: Children go next to their peer, touch and hug them as if trying to comfort them. (c) Positive Response: Children express the same emotion in response to the expression of their peer. (d) Distraction: Children try to draw peer's attention to another activity or play. (e) Directing Attention without Reacting: Children try to listen without showing any reactions and direct quietly their attention to what is happening around them. (f) Negative Response: Children express the opposite emotion in response to the expression of their peer. (g) Physical Excitement Response: Children clap their hands, jump and move their shoulders and body when their peer is happy and lower arms when their peer is sad.

A coding sheet was used for the data analysis using 10 second intervals and whole interval recording technique. Implementation fidelity and inter-observer agreement analyses were carried out. The inter-observer reliability was found to be \%83.33 for the happy emotional expression and \%85.41 for the sad emotional expression. The implementation fidelity of the study was also found to be \%94.44. 


\section{Results} time.

In this study, children's reactions to happy and sad emotional expressions were examined during play

\section{Happy Emotional Expressions}

Table 2

Mann-Whitney U Test Results on Happy Emotional Expressions

\begin{tabular}{clcccccccc}
\hline Variable & \multicolumn{1}{c}{ Group } & $N$ & $S D$ & Mean rank & Sum of ranks & $z$ & $M$ & $U$ & $p$ \\
\hline \multirow{2}{*}{ I } & Visual Impairments & 20 & 1.33 & 29.20 & 584.00 & -5.032 & 1.00 & 26.00 & $.000^{* * *}$ \\
& Sighted & 20 & .52 & 11.80 & 236.00 & & & & \\
C & Visual Impairments & 20 & .00 & 16.00 & 320.00 & -3.354 & .00 & 110.00 & $.001 * *$ \\
& Sighted & 20 & .60 & 25.00 & 500.00 & & & & \\
PR & Visual Impairments & 20 & 1.37 & 12.78 & 255.50 & -4.327 & 2.00 & 45.50 & $.000^{* * *}$ \\
& Sighted & 20 & .82 & 28.23 & 564.50 & & & & \\
D & Visual Impairments & 20 & .00 & 20.50 & 410.00 & .000 & .00 & 200.00 & 1.000 \\
& Sighted & 20 & .00 & 20.50 & 410.00 & & & & \\
DA & Visual Impairments & 20 & .52 & 22.00 & 440.00 & -1.777 & .00 & 170.00 & .076 \\
& Sighted & 20 & .00 & 19.00 & 380.00 & & & & \\
NR & Visual Impairments & 20 & .22 & 21.00 & 420.00 & -1.000 & .00 & 190.00 & .317 \\
& Sighted & 20 & .00 & 20.00 & 400.00 & & & & \\
PE & Visual Impairments & 20 & .00 & 18.00 & 360.00 & -2.360 & .00 & 150.00 & $.018^{*}$ \\
& Sighted & 20 & .44 & 23.00 & 460.00 & & & & \\
\hline
\end{tabular}

Note: $\mathrm{I}=$ ignorance; $\mathrm{C}=$ physical comforting; $\mathrm{PR}=$ positive response, $\mathrm{D}=$ distraction; $\mathrm{DA}=$ directing attention without reacting; $\mathrm{NR}=$ negative response; $\mathrm{PE}=$ physical excitement response.

$* p<.05 ; * * p<.01 ; * * * p<.001$.

Table 3

Kruskal-Wallis H Test Results on Happy Emotional Expressions

\begin{tabular}{|c|c|c|c|c|c|c|c|}
\hline Variable & Group & $N$ & $S D$ & Mean rank & $M$ & $\chi^{2}$ & $p$ \\
\hline I & $\begin{array}{l}\text { Low vision } \\
\text { Severe } \\
\text { Sighted }\end{array}$ & $\begin{array}{l}10 \\
10 \\
20\end{array}$ & $\begin{array}{c}1.64 \\
.51 \\
.52\end{array}$ & $\begin{array}{l}25.90 \\
32.50 \\
11.80\end{array}$ & 1.00 & 27.14 & $.000 * * *$ \\
\hline $\mathrm{C}$ & $\begin{array}{l}\text { Low vision } \\
\text { Severe } \\
\text { Sighted }\end{array}$ & $\begin{array}{l}10 \\
10 \\
20\end{array}$ & $\begin{array}{l}.00 \\
.00 \\
.60\end{array}$ & $\begin{array}{l}16.00 \\
16.00 \\
25.00\end{array}$ & .00 & 11.25 & $.004 * *$ \\
\hline PR & $\begin{array}{l}\text { Low vision } \\
\text { Severe } \\
\text { Sighted }\end{array}$ & $\begin{array}{l}10 \\
10 \\
20\end{array}$ & $\begin{array}{l}1.71 \\
.31 \\
.82\end{array}$ & $\begin{array}{c}17.25 \\
8.30 \\
28.23\end{array}$ & 2.00 & 21.86 & $.000 * * *$ \\
\hline $\mathrm{D}$ & $\begin{array}{l}\text { Low vision } \\
\text { Severe } \\
\text { Sighted }\end{array}$ & $\begin{array}{l}10 \\
10 \\
20\end{array}$ & $\begin{array}{l}.00 \\
.00 \\
.00\end{array}$ & $\begin{array}{l}20.50 \\
20.50 \\
20.50\end{array}$ & .00 & .00 & 1.000 \\
\hline DA & $\begin{array}{l}\text { Low vision } \\
\text { Severe } \\
\text { Sighted }\end{array}$ & $\begin{array}{l}10 \\
10 \\
20\end{array}$ & $\begin{array}{l}.63 \\
.42 \\
.00\end{array}$ & $\begin{array}{l}21.10 \\
22.90 \\
19.00\end{array}$ & .00 & 3.72 & .155 \\
\hline NR & $\begin{array}{l}\text { Low vision } \\
\text { Severe } \\
\text { Sighted }\end{array}$ & $\begin{array}{l}10 \\
10 \\
20\end{array}$ & $\begin{array}{l}.00 \\
.31 \\
.00\end{array}$ & $\begin{array}{l}20.00 \\
22.00 \\
20.00\end{array}$ & .00 & 3.00 & .223 \\
\hline $\mathrm{PE}$ & $\begin{array}{l}\text { Low vision } \\
\text { Severe } \\
\text { Sighted }\end{array}$ & $\begin{array}{l}10 \\
10 \\
20\end{array}$ & $\begin{array}{l}.00 \\
.00 \\
.44\end{array}$ & $\begin{array}{l}18.00 \\
18.00 \\
23.00\end{array}$ & .00 & 5.57 & .062 \\
\hline
\end{tabular}


As seen in Table 2, the reactions to happy expressions were significantly different among Ignorance $(U$ $=26.00, z=-5.032, p<.001)$, Physical Comforting $(U=110.00, z=-3.354, p<.01)$, Positive Response $(U=$ $45.50, z=-4.327, p<.001)$ and Physical Excitement Response $(U=150.00, z=-2.360, p<.05)$ categories between children with visual impairments and sighted children.

As shown in Table 3 , the scores of the happy emotional expressions were significantly different among study groups in Ignorance $(\chi 2=27.14, p<.001)$, Physical Comforting $(\chi 2=11.25, p<.01)$ and Positive Response $(\chi 2=21.86, p<.001)$ categories within children with low vision and severe visual impairments, and sighted children. The post hoc (Dunn-Bonferroni) analysis showed that there was a significant difference within Ignorance between children with low vision and sighted children. Children with low vision scored higher in Ignorance category than sighted children $(p=.001)$. Children with severe visual impairments scored higher than sighted children within the same category $(p=.000)$. There was a significant difference within Physical Comforting between sighted children and children with low vision. The sighted children scored higher than children with low vision $(p=.006)$. Regarding the same category, there was a significant difference between sighted children and children with severe visual impairments. Sighted children scored higher than children with severe visual impairments $(p=.006)$. Finally, there was a significant difference within Positive Response category between sighted children and children with severe visual impairments. The sighted children scored higher than children with severe visual impairments $(p=.000)$. There was also a significant difference between sighted children and children with low vision within the same category. The sighted children scored higher than children with low vision $(p=.012)$.

\section{Sad Emotional Expressions}

Table 4

Mann-Whitney U Test Results on Sad Emotional Expressions

\begin{tabular}{|c|c|c|c|c|c|c|c|c|c|}
\hline Variable & Group & $N$ & $S D$ & Mean rank & Sum of ranks & $z$ & $M$ & $U$ & $p$ \\
\hline \multirow{2}{*}{ I } & Visual Impairments & 20 & 1.44 & 26.03 & 520.50 & -3.140 & 1.00 & 89.50 & $.002 * *$ \\
\hline & Sighted & 20 & .82 & 14.98 & 299.50 & & & & \\
\hline \multirow{2}{*}{$\mathrm{C}$} & Visual Impairments & 20 & .00 & 17.00 & 340.00 & -2.870 & .00 & 130.00 & $.004 * *$ \\
\hline & Sighted & 20 & .59 & 24.00 & 480.00 & & & & \\
\hline \multirow{2}{*}{ PR } & Visual Impairments & 20 & 1.14 & 16.43 & 328.50 & -2.294 & 1.50 & 118.50 & $.022 *$ \\
\hline & Sighted & 20 & 1.05 & 24.58 & 491.50 & & & & \\
\hline \multirow{2}{*}{$\mathrm{D}$} & Visual Impairments & 20 & .00 & 20.00 & 400.00 & -1.000 & .00 & 190.00 & .317 \\
\hline & Sighted & 20 & .22 & 21.00 & 420.00 & & & & \\
\hline \multirow{2}{*}{ DA } & Visual Impairments & 20 & .67 & 24.53 & 490.50 & -2.432 & 1.00 & 119.50 & $.015^{*}$ \\
\hline & Sighted & 20 & .48 & 16.48 & 329.50 & & & & \\
\hline \multirow{2}{*}{ NR } & Visual Impairments & 20 & .80 & 19.65 & 393.00 & -.659 & .00 & 183.00 & .510 \\
\hline & Sighted & 20 & .74 & 21.35 & 427.00 & & & & \\
\hline \multirow{2}{*}{$\mathrm{PE}$} & Visual Impairments & 20 & .00 & 16.00 & 320.00 & -3.354 & .00 & 110.00 & $.001 * *$ \\
\hline & Sighted & 20 & .60 & 25.00 & 500.00 & & & & \\
\hline
\end{tabular}

Note: $\mathrm{I}=$ ignorance; $\mathrm{C}=$ physical comforting; $\mathrm{PR}=$ positive response $\mathrm{D}=$ distraction; $\mathrm{DA}=$ directing attention without reacting; $\mathrm{NR}=$ negative response; $\mathrm{PE}=$ physical excitement response.

$* p<.05 ; * * p<.01 ; * * * p<.001$.

Table 4 showed that the reactions to sad expressions were significantly different among study groups in Ignorance $(U=89.50, z=-3.140, p<.01)$, Physical Comforting $(U=130.00, z=-2.870, p<.01)$, Positive Response $(U=118.50, z=-2.294, p<.05)$, Directing Attention without Reacting $(U=119.50, z=-2.432, p<.05)$ and Physical Excitement Response $(U=110.00, z=-3.354, p<.01)$ categories between children with visual impairments and sighted children. 
Table 5

Kruskal-Wallis H Test Results on Sad Emotional Expressions

\begin{tabular}{|c|c|c|c|c|c|c|c|}
\hline Variable & Group & $N$ & $S D$ & Mean rank & $M$ & $\chi^{2}$ & $p$ \\
\hline \multirow{3}{*}{ I } & Low vision & 10 & 1.56 & 20.70 & 1.00 & 14.43 & $.001 * *$ \\
\hline & Severe & 10 & 1.08 & 31.35 & & & \\
\hline & Sighted & 20 & .82 & 14.98 & & & \\
\hline \multirow{3}{*}{$\mathrm{C}$} & Low vision & 10 & .00 & 17.00 & .00 & 8.23 & $.016 *$ \\
\hline & Severe & 10 & .00 & 17.00 & & & \\
\hline & Sighted & 20 & .59 & 24.00 & & & \\
\hline \multirow{3}{*}{ PR } & Low vision & 10 & 1.28 & 17.90 & 1.50 & 5.61 & .061 \\
\hline & Severe & 10 & 1.03 & 14.95 & & & \\
\hline & Sighted & 20 & 1.05 & 24.58 & & & \\
\hline \multirow{3}{*}{$\mathrm{D}$} & Low vision & 10 & .00 & 20.00 & .00 & 1.00 & .607 \\
\hline & Severe & 10 & .00 & 20.00 & & & \\
\hline & Sighted & 20 & .22 & 21.00 & & & \\
\hline \multirow{3}{*}{ DA } & Low vision & 10 & .81 & 26.10 & 1.00 & 6.36 & $.041 *$ \\
\hline & Severe & 10 & .48 & 22.95 & & & \\
\hline & Sighted & 20 & .48 & 16.48 & & & \\
\hline \multirow{3}{*}{ NR } & Low vision & 10 & 1.07 & 22.80 & .00 & 3.42 & .181 \\
\hline & Severe & 10 & .00 & 16.50 & & & \\
\hline & Sighted & 20 & .74 & 21.35 & & & \\
\hline \multirow{3}{*}{ PE } & Low vision & 10 & .00 & 16.00 & .00 & 11.25 & $.004 * *$ \\
\hline & Severe & 10 & .00 & 16.00 & & & \\
\hline & Sighted & 20 & .60 & 25.00 & & & \\
\hline
\end{tabular}

As shown in Table 5, the scores were significantly different among study groups in Ignorance $(\chi 2=14.43$, $p<.01)$, Physical Comforting $(\chi 2=8.23, p<.05)$, Directing Attention without Reacting $(\chi 2=6.36, p<.05)$ and Physical Excitement Response $(\chi 2=11.25, p<.01)$ categories between the children with low vision, children with severe visual impairment and sighted children. The post hoc (Dunn-Bonferroni) analysis showed that there was a significant difference within Ignorance category between children with severe visual impairments and sighted children. Children with severe visual impairments scored higher than sighted children in this category $(p=.000)$. Children with severe visual impairments scored higher than children with low vision in the same category ( $p=$ .032). There was a significant difference within Physical Comforting category between sighted children and children with low vision. The sighted children scored higher than children with low vision $(p=.019)$. There was a significant difference between sighted children and children with severe visual impairments in the same category. Sighted children scored higher than children with severe visual impairments $(p=.019)$. There was a significant difference within Directing Attention without Reacting category between children with low vision and sighted children. The children with low vision scored higher than sighted children $(p=.018)$. There was a significant difference within Physical Excitement Response category between sighted children and children with low vision. The sighted children scored higher than children with low vision $(p=.006)$. There was a significant difference between sighted children and children with severe visual impairments in the same category. The sighted children scored higher than children with severe visual impairments $(p=.006)$.

\section{Discussion}

Children's reactions to happy and sad emotional expressions were examined in this study. Findings showed that children with severe visual impairments were more ignored and unresponsive to their peer's sad emotional expressions than children with low vision. This finding indicated that children with visual impairments' emotional expressions may be affected from their visual problems.

Happy emotional expressions also differed within Ignorance, Physical Comforting and Positive Response categories between children with severe visual impairments, children with low vision, and sighted children. Children with low vision and severe visual impairments scored higher than sighted children within Ignorance 
category. However, sighted children scored higher in Physical Comforting and Positive Response categories. Children with visual impairments exhibited more ignoring reactions to peer's happy expressions. This finding suggests that children with visual impairments may not be as responsive as their sighted peers to other's feelings. For example, following the play, some children with visual impairments prefered to sit quietly without talking to their peers when their peers received a prize. However, sighted children displayed more physical warmth and positive response reactions to their peer's happiness. Study findings indicated that sighted children displayed clearly that they share the same feelings as their peer's and made more physical contact while expressing their feelings. Some of the sighted children were observed hugging their peers when their peers received the prize after the game.

Sad emotional expressions differed within Ignorance, Physical Comforting, Directing Attention without Reacting and Physical Excitement Response categories among children with severe visual impairments, children with low vision, and sighted children. Children with severe visual impairments scored higher within Ignorance category than children with low vision and sighted children. Study findings showed that sighted children scored higher than other children (with low vision and severe visual impairments) in Physical Comforting and Physical Excitement Response categories. Children with low vision scored higher within Directing Attention without Reacting category than sighted children. Children with visual impairments were observed as less responsive to their peers' emotional reactions as many of them did not appear to direct their attention to their peers or listen to what was happening around them. For example, some of the children with visual impairments tried to listen without showing any reactions when their peers could not receive the toy. However, sighted children displayed more physical activity towards their peers (e.g., hugging, going up to peer) when they could not receive the toy. For instance, some of the sighted children turned their gaze towards the face of their peer when their peer could not receive the toy, they went next to their peer and hugged her/him as if they are trying to comfort them.

This study compared reactions to emotional expressions of others in three groups of children; children with severe visual impairments, children with low vision, and sighted children. The study included two major positive and negative emotions: Sad and happy. Future studies may examine children's reactions to other emotional expressions such as curiosity, confusion, fear, anger, and disgust. This study was conducted with preschool children. Children with visual impairment's emotional expressions can also be examined during middle childhood (6-12 years), adolescence, and adulthood years. 